\title{
Plant 'pathogenesis-related' proteins and their role in defense against pathogens
}

\author{
A Stintzi ${ }^{\mathrm{a}}$, T Heitz ${ }^{\mathrm{a}}$ V Prasad ${ }^{\mathrm{b}}, \mathrm{S}$ Wiedemann-Merdinoglu, \\ S Kauffmann ${ }^{\mathrm{a}}$, P Geoffroy ${ }^{\mathrm{a}}$, M Legrand ${ }^{\mathrm{a}}$, B Fritig ${ }^{\mathrm{a} *}$ \\ alnstitut de Biologie Moléculaire des Plantes du CNRS, Université Louis Pasteur; \\ 12 rue du Général Zimmer, 67000 Strasbourg, France; \\ DDepartment of Botany, University of Luknow, India; \\ INRA, 28, rue de Herrlisheim, 6802I Colmar Cedex, France
}

\begin{abstract}
Summary - The hypersensitive reaction to a pathogen is one of the most efficient defense mechanisms in nature and leads to the induction of numerous plant genes encoding defense proteins. These proteins include: 1) structural proteins that are incorporated into the extracellular matrix and participate in the confinement of the pathogen; 2) enzymes of secondary metabolism, for instance those of the biosynthesis of plant antibiotics; 3 ) pathogenesis-related (PR) proteins which represent major quantitative changes in soluble protein during the defense response. The PRs have typical physicochemical properties that enable them to resist to acidic $\mathrm{pH}$ and proteolytic cleavage and thus survive in the harsh environments where they occur: vacuolar compartment or cell wall or intercellular spaces. Since the discovery of the first PRs in tobacco many other similar proteins have been isolated from tobacco but also from other plant species, including dicots and monocots, the widest range being characterized from hypersensitively reacting tobacco. Based first on seroloyical properties and later on sequence data, the tobacco PRs have been classified in five major groups. Group PR- 1 contains the first discovered PRs of 15-17 kDa molecular mass, whose biological activity is still unknown, but some members have been shown recently to have antifungal activity. Group PR-2 contains three structurally distinct classes of $1,3-\beta$-glucanases, with acidic and basic counterparts, with dramatically different specific activity towards linear I,3- $\beta$-glucans and with different substrate specificity. Group PR-3 consists of various chitinases-lysozymes that belong to three distinct classes, are vacuolar or extracellular, and exhibit differential chitinase and lysozyme activities. Some of them, either alone or in combination with $1,3-\beta$-glucanases, have been shown to be antifungal in vitro and in vivo (transgenic plants), probably by hydrolysing their substrates as structural components in the fungal cell wall. Group PR-4 is the less studied, and in tobacco contains four members of 13-14.5 kDa of unknown activity and function. Group PR-5 contains acidic-neutral and very basic members with extracellular and vacuolar localization, respectively, and all members show sequence similarity to the sweet-tasting protein thaumatin. Several members of the PR-5 group from tobacco and other plant species were shown to display significant in vitro activity of inhibiting hyphal growth or spore germination of various fungi probably by a membrane perneabilizing mechanism. We have isolated several other tobacco PRs that cannot be classified in these five major groups: two hydrolases with $\alpha$-amylase activity, two inhibitors of microbial proteases, two peroxidases, two basic proteins of 16 and $45 \mathrm{kDil}$ of unknown activity. In conclusion, among the 33 isolated tobacco PRs, 31 have been characterized and 25 are members of live major groups also found in other plant species. Most of the PRs (groups PR-1, PR-2, PR-3, PR-5, $\alpha$-amylases, inhibitors of microbial proteases) can be considered as direct antimicrobial defense proteins or enzymes. Some of them might also be indirectly antimicrobial. for instance PRs-2 and PRs-3 by releasing elicitor-active oligosaccharides, and peroxidases by catalysing cross-linking of macromolecules in the cell wall.
\end{abstract}

hypersensitive response / chitinase-lysozyme / I,3-3-glucanase / prateinase inhibitor / membrane permeabilization

\section{Introduction}

Pathogenesis-related (PR) proteins were first detected in the early 1970 s $[1,2]$ in tobacco leaves reacting hypersensitively to tobacco mosaic virus (TMV). This is the biological system that we are also using and

*Correspondence and reprints from which the highest number of PR-proteins have been characterized so far.

The hypersensitive reaction to pathogen attack is considered as a very strong defense response induced in plants by the pathogen itself. It follows the phenomenon of gene-for-gene complementarity [3--6] between plant and pathogen. In the presence of dominant, matching alleles of a pathogen avirulence gene and of a plant disease resistance gene, recognition 
occurs and the plant responds to infection by producing the hypersensitive response [7-9]. Necrotic lesions are formed around the initial sites of pathogenic attack. The pathogen will be restricted to a zone of cells surrounding the necrotic lesions, as a result of a very intense deiense response that is induced in this ring of cells [10]. In the case of the hypersensitive response of tobacco to TMV, the zones of highly-induced defense responses can easily be detected under UV light as rings of cells exhibiting bright blue fluorescence and surrounding the necrotic lesions. These cells have accumulated derivatives of the phenylpropanoid pathway [11-13], some of which are fluorescent, and thus represent good indicators of defense responsive cells. Other low molecular mass components accumulate equally well in these cells and have antimicrobial activity, the so-called 'phytoalexins' [14-17]. But many other changes occur in the same cells $[10,18,19]$. For instance, cell wall thickening and reinforcement by deposition of various macromolecules such as carbohydrates (callose), proteins [20] and hydroxyproline-rich glycoproteins [21], aromatic polymers such as lignin, lignin-like material or other yet undefined cell wall bound phenolics [22, 23]. Another important change which occurs in the fluorescent cells is the production of the numerous PR-proteins which, after a few days post-inoculation, may account for $10 \%$ of the content of the leaves in soluble proteins [24-29].

Some of these changes are strictly localized around the infection sites, for instance the accumulation of fluorescent phenylpropanoid metabolites of tobacco [12] or gener:ally in most plant species the production of low molecular inass antimicrobial substances $[10$, 17]. However, some of the changes are also induced at distance from the infection sites and even in uninoculated and uninfected parts of partially-infected plants, though to a much lower extent than locally. This is the case for some of the PR-proteins, whose production in uninoculated tobacco leaves represents 5-10\% of their production in inoculated hypersensitively reacting leaves. Even though this 'systemic' defense response is of much lower cellular intensity than the local response it still represents a massive amplification in the response since it concems the whole plant. Furthermore, this systemic defense response is accompanied by the phenomenon of 'systemic acquired resistance'. If part of a plant has already reacted hypersensitively to a pathogen, the uninoculated parts of this plant develop an increased state of resistance evidenced by smaller lesions and greater restriction of the infection upon challenge inoculation by the same or any other unrelated but necrotizing pathogen [30-37]. Since the PR-proteins are induced in parallel with the appearance of systemic acquired resistance they are believed to participate in its efficiency, but a causal relationship has still not been clearly proven. They represent also very interesting and sensitive markers for the search of the signals involved that are moving from the primary sites of necrotizing infection to distant sites where both systemic acquired resistance and PRproteins are induced [38].

\section{Occurrence, induction and general properties of PR-proteins}

Since the discovery of the first four PR-proteins in tobacco [1, 2], many other proteins with similar physicochemical and induction properties have been isolated from tobacco (see below) as well as from many other plant species, including dicots and monocots.

It has been reported that PRs are produced during the response of plants to infection by viruses, viroids, bacteria or fungi (for reviews see [26, 39-43]). Very interestingly, they are produced constitutively in interspecific hybrids which exhibit high constitutive resistance to viral infection [44]. However, at least some members of the different PR families have been found to be induced under treatments with chemicals such as polyacrylic acid [45], amino acid derivatives [46], heavy metal salts $[47,48]$, aspirin and salicylic acid $[40,42,49-54]$ and air pollutants $[55,56]$. Some PRs are also induced by treatments with phytohormones. Even though cases of induction by auxins $[57,58]$ or cytokinins [59, 60] are known, the pattern of induction by these two hormones is unclear, except under conditions of strong disturbance in the balance between them which lead to high induction of various families of PRs [61-65]. Some PRs are induced under osmotic stress or salt stress conditions $[66,67]$ with a possible involvement of abscisic acid [68]. Another phytohormone, ethylene, considered as a 'stress' hormone, is a potent inducer of PR proteins [58-60, 6977]. PR production has also been shown to be developmentally regulated in healthy plants since high levels of some PRs have been reported in roots and senescent leaves $[60,62,64,66,78,79]$, and during flowering [80-84].

Since PRs are induced under so many different conditions where pathogens are not involved, should they still be called 'pathogenesis-related'? In fact, the widest range of PRs in a given plant species is induced in response to pathogens (see below) and, therefore, this name appears still justified. Furthermore, it is known that during response of plants to pathogens, and particularly in necrotic infections, metabolic alterations include the production of the stress hormones ethylene and possibly abscisic acid, the synthesis and migration of the strong PR inducer salicylic acid [51-53,85-87] and changes in the balance between auxins and cytokinins. As mentioned above, all these individual changes have the potential 
to induce the production of a given set of PRs, and, hence, it is not surprising that the response to necrotic infections which produces a combination of these inducers is accompanied by the induction of the widest array of PRs.

PR-proteins display very characteristic physicochemical properties which aid in their detection and isolation: 1) they are very stable at low $\mathrm{pH}$ and remain soluble (for instance in an extraction buffer of $\mathrm{pH} 2.8$ ) whereas most other plant proteins are denatured; 2) they are relatively resistant to the action of proteolytic enzymes of endogenous but also exogenous origin; 3 ) they are monomers (with a few exceptions, see below) of rather low molecular mass (8-50 kDa); 4) they are localized in compartments such as the vacuole, the cell wall and/or the apoplast. Properties $1), 2$ ), and 4) are tightly related, ie the high level of resistance of PRs to acidic $\mathrm{pH}$ and to protease action appear to be well adapted to these harsh environments where they occur. Resistance to proteases also suggests that the PRs have a low turnover. There has been a report, however, indicating a degradation of PRs by an extracellular aspartyl protease which might be responsible for PR tumover in tomato [88].

One can wonder whether the conditions of induction or these physicochemical properties should be taken into account to define a protein as pathogenrelated. In the opinion of the authors, rather than giving priority to the induction conditions which are common to many other defense-related proteins and enz:/mes, one should consider high resistance to very acidic medium and to proteases as an additional property of PRs, since they enable these proteins to survive in very hostile environments to which they are targeted: the vacuolar compartment, the intercellular spaces and the cell wall.

\section{Classification of PR-proteins}

The first four discovered PRs [1, 2] could easily be detected because of their very high mobility in native basic polyacrylamide gels and because they migrated to a zone of the gel containing very few other cellular proteins. Other, less mobile PRs were present in the same gels but could not be resolved from the numerous proteins with similar mobilities. The procedure of extraction at low $\mathrm{pH}$ introduced in the late 1970s eliminated most of the less mobile proteins, and a comparison of the gels loaded with extracts from tobacco leaves reacting hypersensitively to TMV or from healthy leaves revealed six other bands of PRs [24]. These 10 major acidic tobacco PRs were well resolved upon electrophoresis on these native basic gels and their nomenclature was based on their relative electrophoretic mobility. They have been referred to as $\mathrm{PR}-\mathrm{la},-\mathrm{lb},-\mathrm{lc},-2,-\mathrm{N},-\mathrm{O},-\mathrm{P},-\mathrm{Q},-\mathrm{R}$ and $-S$ in order of decreasing mobility (fig 1) [89]. PR-la, $-1 b$ and -lc were studied extensively and shown to be serologically related. We purified to homogeneity the seven other PRs [27, 90] and demonstrated that they were members of three other distinct serological families containing PR-2, $-N$ and O, PR-P and -Q, PR-R and -S, respectively [90]. The availability of these proteins in their native form enabled us to assign biological functions to five of these proteins which have remained mysterious for 15 years: we demonstrated that PR-2, $-\mathrm{N}$ and $-\mathrm{O}$ had endo-1,3- $\beta$-glucanase activity [91] and that the major proteins PR-P and $-Q$ had endo-chitinase activity [92]. This finding could then be extended to other plant species from which PRs were also identified as endo1,3- $\beta$-glucanases or endo-chitinases [93-98].

In the late $1980 \mathrm{~s}$, proteins similar to those of tobacco were detected or characterized in many plant species, their cDNAs and gene(s) cloned, so that many sequence data became available. They confirmed sequence similarities between the PRs mentioned above having chitinase or glucanase activity

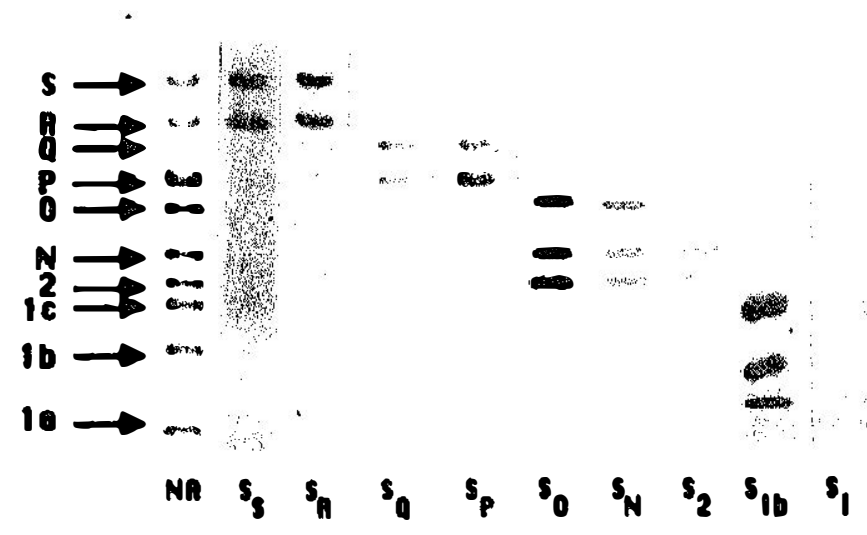

Fig 1. Serological relationships between the 10 acidic extracellular PR-proteins initially detected in tobacco by their resistance to acidic $\mathrm{pH}$ and to protease cleavage [24]. A mixture of the 10 proteins purified according to $[90,99]$ were submitted to slab gel electrophoresis under non-denaturing conditions, as described in [92]. After electrophoretic transfer onto nitrocellulose sheets, the proteins were stained with amido black (lane NA) or immunodetected with sera raised against proteins $P R-S,-R,-Q,-P,-O,-N,-2$ and $-1 b$ (lanes $S_{S}, S_{R}, S_{Q}, S_{p}, S_{O}, S_{N}, S_{2}$ and $S_{1 b}$, respectively), or incubated with a preimmune serum (lane $S_{1}$ ). Note that the proteins are well resolved from each other under the native conditions of electrophoresis used and that, in addition to the known PR-1 serological group containing three proteins $[26,89]$ there are three other distinct serological groups including two, two and three proteins, respectively. 
Table I. The tobacco PR-1 group: antifungal proteins. Proteins PR- $1 \mathrm{a},-1 \mathrm{~b}$ and $-1 \mathrm{c}$ were isolated according to $[27,90]$. Protein PR-1g has been isolated recently by the authors (unpublished results) and its amino acid sequence is almost identical to that deduced from previously described cDNA and genomic clones $[109,110]$. The nomenclature is that proposed in [29, 111]. Similar boxes indicate demonstrated serological relationships. Molecular mass values are either deduced from corresponding cloned cDNA or calculated from relative mobility upon electrophoresis of the proteins under denaturing conditions. Values of $\mathrm{pl}$ are calculated from the amino acid sequences or elution $\mathrm{pH}$ have been measured in chromatofocusing experiments. The localization is referred to 'ext' for extracellular and 'int' for intracellular occurrence of the protcins.

\begin{tabular}{ccccc}
\hline $\begin{array}{c}\text { Name } \\
\text { Molccular mass } \\
\text { (kDa) }\end{array}$ & $\begin{array}{c}\text { Ehtution ph } \\
\text { (chromatofocusing) }\end{array}$ & Localization & $\begin{array}{c}\text { Biolugical } \\
\text { activity }\end{array}$ \\
\hline Ia & 15.5 & $<7$ & ext & antifungal \\
\hline Ib & 15.5 & 4.5 & ext & antifungal \\
\hline Ic & 15 & 4.7 & ext & $?$ \\
\hline Ig & 17 & $>7$ & ext & $?$ \\
\hline
\end{tabular}

and well known constitutive plant chitinases and glucanases, respectively. Howevei; they usually did not give any clue to the biological activity or function of the other families of PRs.

We have extended our studies in tobacco by both molecular biology and biochemical approaches. Concerning the biochemistry, we used a combination of conventional and HPLC means of chromatography involving a cascade of steps based on various physicochemical properties of the proteins [99]. These steps include cation or anion exchange chromatogriphy, chromatofocusing, hydrophobic interaction and molecular sieving. By combining these steps we were able to isolate up to now from tobacco, that is still considered as a prototype system for PR-proteins, more than $30 \mathrm{PR}$-proteins. Isolation of these proteins in their native form allowed us to raise antibodies, but the major advantage of having them in the native form was the possibility to determine and compare their specific biological activities.

Among the newly-isolated proteins some are related to the 10 acidic extracellular proteins already described in tobacco. Some are obviously members of new families in tobacco, but are related to proteins of other plant species. At the 3rd International Workshop on PR-proteins (Arolla, Switzerland, August 16-20, 1992) it was agreed that to enable an easier comparison of related PR-proteins members between different plant species, a common classification and way of nomenclature should be used. It was particularly agreed and recognized that five families or groups of PR-proteins have been found in most studied plant species and, thus, appear to be ubiquitous.

The following paragraphs will describe these different groups and their possible role in defense, taking the tobacco PRs as the model system.

\section{The PR-1 group}

The present stage of knowledge concerning tobacco proteins of group 1 is summarized in table I. Tobacco acidic PRs of group l (PR-la, -lb and -lc) were the subject of most of the earlier work. They were the first to be purified $[27,89,100]$ and were shown to belong to a serological group in tobacco and to be serologically related to PRs from other plant species [94, 101-103]. cDNA clones encoding the acidic tobacco PRs of group 1 were isolated from cDNA libraries derived from mRNA extracted from leaves reacting hypersensitively to TMV [104-108]. It was shown that these three proteins have sequence similarity higher than $90 \%$ and that their increased synthesis is under transcriptional control. They are encoded by a small family of at least eight genes [109] and several of these genes have been isolated from genomic libraries (for reviews see $[40,42]$ ). cDNAs and genomic clones corresponding to a basic protein which has approximately $65 \%$ similarity to $\mathrm{PR}-\mathrm{la},-\mathrm{lb}$ and $-\mathrm{lc}$ have also been characterized from TMV-infected leaves $[109,110]$. Using the antibodies raised against tobacco acidic PR-1 proteins, it was not possible to detect basic PR-I protein(s). Recently, we were able to isolate a basic $17 \mathrm{kDa}$ protein and partial microsequencing indicated almost complete identity to the protein sequences deduced from the cDNA and genomic clones (Fritig al al, unpublished). According to the rules proposed by a nomenclature committee for PR-proteins, this basic member should be called PR-lg [111].

Comparison of the amino acid sequences of all known PRs-1 with those available in data banks did not give any clue about the potential biological activity or function of these proteins $[105,112]$. Since they were the first discovered PRs in response to viruses, they have been believed to participate in resistance to viruses or in their localization. Consistent with this hypothesis several treatments that induced PRs-1 in tobacco were also efficient inducers of resistance to viruses. Another strong argument was provided by the interspecific hybrids of Nicotiana glutinosa $\times$ Nicotiana debneyi that produced constitutively PRs-1 and were highly resistant to TMV [44]. This question was addressed further by producing transgenic tobacco plants expressing PR-la or PR-Ib genes constitutively $[113,114]$. In transformed plants the protein encoded by the chimeric gene was produced and targeted to the extracellular spaces, as expected. However, these plants did not show higher 
levels of resistance to virus infection, and apparently represent an argument that breaks the correlation between high levels of resistance to vinis and high levels of PRs-1.

Some data are already available, suggesting that some PR-1 miembers have antifungal activity. It has been shown recently [115] that three members of the PR-1 group from tomato had antifungal activity in in vitro assays against Phytophthora infestans. In the same assays, PR-la and PR-1b from tobacco showed lower but still significant activity of inhibiting Phytophthora infestans (Niderman and Fritig, unpublished). This activity observed in vitro for PR-la is consistent with recent results obtained in vivo by the group of John Ryals [38]: they observed that transgenic tobacco plants expressing constitutively high levels of PR-1a exhibited a significant protection from infection by Peronospora tabacina that causes the blue mold disease of tobacco.

It will be now interesting to assay other PRs-1 of various plant species for antimicrobial activity and to investigate the molecular mechanism(s) involved.

\section{The PR-2 (1,3- $\beta$-glucanase) and PR-3 (chitinase) groups}

Since the discovery that major tobacco PR-proteins had endo-chitinase [92] and endo-1,3- $\beta$-glucanase activity [91], the literature on plant chitinases and 1,3$\beta$-glucanases has grown to such an extent that a comprehensive analysis is beyond the limitations of this review which will not deal with the structure and the regulation of their genes, but will focus merely on their biological activities and their role in defense.

Properties and biological activities of PRs-2 (1,3- $\beta$ glucanases)

Many 1,3- $\beta$-glucanases have been purified and characterized (for a review see [116]). Like most of the
PR-proteins, they usually are monomers with a molecular mass in the 25-35-kDa range. Most are endoglucanases, producing oligomers of chain lengths of 2-6 glucose units from the classical substrate laminarin, an almost unbranched $1,3-\beta$-glucan, or from other $1,3-$ $\beta$-glucans. Many glucanases from various plant species have been cloned and sequenced (for a review see [117]). On the basis of a comparison of the deduced amino acid sequences of tobacco $1,3-\beta$-glucanases, they have been grouped into three classes [118-120].

From tobacco we have isolated five distinct members (table II): four acidic enzymes and a major basic enzyme (that consists perhaps of several closely related isoforms, as suggested by two-dimensional polyacrylamide gel electrophoresis [67]). The latter is a class I enzyme, PR-2, $-\mathrm{N}$ and $-\mathrm{O}$ are of class II, and another extracellular enzyme, PR-Q' has to be considered in the separate class III according to sequence data [118]. They all are serologically related $[90,91]$. A protein called $\mathrm{O}^{\prime}$, migrating like $\mathrm{PR}-\mathrm{O}$ in native basic gels [99], did not cross-react with anti-glucanase antibodies, has a dimeric structure, and was found to possess no glucanase activity after several successive chromatographic steps aimed to remove any contamination by PR-O. The acidic enzymes are extracellular $[90,91]$ whereas the basic counterpart occurs in the vacuoles [72, 121]. Another 1,3- $\beta$-glucanase called sp41 has been found in large amounts in specific flower organs [81]. Unlike other PRs of group 2, sp41 is glycosylated and has not been found after TMV infection.

We have measured the specific activity of these enzymes towards laminarin as the substrate, and, surprisingly found pronounced differences, exceeding two orders of magnitude (table II). It is noteworthy that there is no correlation between the level of sequence similarity and the relative catalytic activity of the enzymes: PR-proteins 2 and $\mathrm{N}$ show 99\% amino acid similarity but $\mathbf{N}$ was found five times

Table II. The tobacco PR-2 group: 1,3- $\beta$-glucanases. The proteins were isolated according to $[90,91,99]$. The different classes are based on differences in amino acid sequence as described in [117-120]. Specific enzymatic activ ity has been measured with laminarin as the substrate as described in [91]. Relative specific activity is expressed as the percentage of the highe st specific activity. For all other items, see legend to table $\mathrm{l}$.

\begin{tabular}{cccccc}
\hline Name & Class & $\begin{array}{c}\text { Molecular mass } \\
(k D a)\end{array}$ & $\begin{array}{c}\text { Elution pH } \\
\text { (chromatofocusing) }\end{array}$ & Localization & $\begin{array}{c}\text { Relative specific } \\
\text { activitics }(\%)\end{array}$ \\
\hline $\mathbf{2}$ & II & 31 & 4.4 & ext & 0.4 \\
\hline N & II & 33 & 4.7 & ext & 1.8 \\
\hline O & II & 35 & 4.8 & ext & 85 \\
\hline Q' & III & 35 & 5.3 & ext & 3.8 \\
\hline glucb & I & 33 & $>7$ & int & 100 \\
\hline
\end{tabular}


Table III. The tobacco PR-3 group: chitinases - lysozymes. Proteins chi 34, chi 32, P and Q were isolated according to [90, 92 , 99]. Proteins chi 28 , lys $28 \mathrm{a}$, lys bl and lys b2 have been isolated recently by the authors (unpublished results). The different classes are based on differences in amino acid sequence as described in [117, 123, 131-133]. Chitinase and lysozyme activities were measured as described in [92] and [126], respectively. For all other items, see legend to table $\mathrm{I}$.

\begin{tabular}{|c|c|c|c|c|c|c|}
\hline Name & Class & $\begin{array}{l}\text { Molecular mass } \\
\quad(k D a)\end{array}$ & $\begin{array}{c}\text { Isoelectric point } \\
\text { (elution pH })\end{array}$ & Localization & $\begin{array}{l}\text { Relative sp } \\
\text { Chitinase }\end{array}$ & $\begin{array}{l}\text { activities (\%) } \\
\text { Lysozyme }\end{array}$ \\
\hline chi 34 & Ia & 34 & $>7$ & int & 100 & 10 \\
\hline $\operatorname{chi} 32$ & Ia & 32 & $>7$ & int & 100 & 10 \\
\hline chi 28 & Ib & 28 & $>7$ & ext & 30 & 10 \\
\hline $\mathbf{P}$ & IIa & 27 & (5.3) & ext & 20 & $\mathbf{0}$ \\
\hline $\mathbf{Q}$ & IIa & 28 & (5.8) & ext & 20 & $\mathbf{0}$ \\
\hline lys 28a & III & 28 & 4.4 & ext & 10 & $\mathbf{0}$ \\
\hline$|y, b|$ & III & 28 & 8.3 & ext & 10 & 80 \\
\hline lys b2 & III & 28 & 8.3 & ext & 20 & 100 \\
\hline
\end{tabular}

more active than 2; likewise PR-O is $93 \%$ similar to PR-2 in amino acid sequence but is 250 times more active. It has an activity similar to that of the basic glucanase, even though the two amino acid sequences are very different so that they fall into distinct classes (table II). This raises the problem of differences in substrate specificity between glucanases of a given plant species and also between glucanases of different plant species.

Clear evidence for such differences in substrate specificity was obtained in a collaborative work with P Albersheim and A Darvill (Complex Carbohydrate Research Center, Athens, Georgia, USA). They purified to homogelicity a soybein $1.3-\beta$-glucinase [122] that shows also high specific activity towards laminarin, like PR-proteins $\mathrm{O}$ and gluc $b$ of tobacco (table II). Preparations of pure soybean glucanase and of the most active tobacco glucanases were adjusted to the same activity towards laminarin and faced with another substrate consisting of a preparation of cell walls from the fungus Phytophthora megasperma, a pathogen of soybean. Very striking differences in activity were observed for the different glucanases: the tobacco enzymes had no significant activity towards this substrate, whereas the soybean glucanase was very active (Fritig ef al, unpublished). In conclusion, it appears that 1,3- $\beta$-glucanases may differ very much in specific activity towards a given substrate and more generally in substrate specificity.

\section{Properties and biological activities of PRs-3 (chitinases-lysozymes)}

A large number of chitinases have been purified and characterized (for reviews see [116, 123]). Like the glucanases they are usually monomers of $25-35-\mathrm{kDa}$ molecular mass. Most plant chitinases characterized so far are endochitinases, producing chito-oligosaccharides of 2-6 N-acetylglucosamine units. Many purified plant endochitinases also possess some lysozyme activity, ie they can hydrolyse $\beta$-1,4-linkages between $\mathbf{N}$-acetylmuramic acid and $\mathbf{N}$-acetylglucosamine in the bacterial peptidoglycan [116, 124-127]. Likewise, móst plant lysozymes show significant levels of chitinase activity [126-128]. Some chitinases also act as chitosanases but, in addition, specific chitosanases are induced in plants in response to pathogens [129].

In response to TMV infection, tobacco plants produce PR-P and PR-Q as the major acidic PRs. We showed [92] that they hydrolysed efficiently chitin, a polymer of $\beta-1,4-\mathrm{N}$-acetylglucosamine, that is a major component of the exoskeleton of insects and of the cell wall of most fungi. This was very surprising since the inducing pathogen, TMV, does not contain chitin. Furthermore, two other chitinases of basic isoelectric point (chi 32 and chi 34) were also found induced by TMV infection. Chi 32 and chi 34 are the most active enzymes and account for about $70 \%$ of the total chitinase activity in TMV-infected tobacco extracts. These forms have been detected in other situations, for instance in tobacco tissue and protoplast cultures $[64,67]$ and, like other basic members of other groups of PRs, in roots and old leaves of tobacco [64]. The basic chitinases chi 32 and chi 34 have also lysozyme activity, in contrast to chitinases $\mathbf{P}$ and $\mathbf{Q}$ (table III). Recently a third basic chitinase, chi 28 , closely related to chi 32 and 34 has been isolated (Stintzi et al, unpublished). Furthermore, two other basic proteins, lys bl and lys b2, have been isolated and demonstrated to have high lysozyme activity on Micrococcus luteus cells (Stintzi $e t$ al, unpublished) and a significant chitinase activity. Antibodies raised against lys b1 recognized lys b2 and 
a novel acidic protein called lys $28 \mathrm{a}$. The latter was purified and, surprisingly showed no significant lysozyme activity in the assay with Micrococcus luteus cells. Since at the $\mathrm{pH}$ of incubation there could be repulsion effects of negative charges between the enzyme and the substrate, we used another classical substrate of lysozymes, 4-methylumbelliferyl-chitotriose, and found that all three lysozymes had high activity towards this substrate (Stintzi et al, unpublished).

Concerning the localization of the different members of tobacco chitinases-lysozymes, some are vacuolar proteins while others are extracellular. Till recently, all acidic tobacco proteins had been found to be extracellular and all their basic counterparts localized in the vacuoles [40]. Now, in addition to PR-1g (table I) which is an extracellular basic protein, table III reveals three other basic proteins that are targeted to the extracellular spaces: chi 28 , lys bl and lys b2.

Comparison of deduced amino acid sequences of cDNA and genomic clones indicates that there are at least three classes of chitinases in tobacco [123]. Class I contains the basic chitinases with a $\mathrm{N}$-terminal cysteine-rich domain of approximately 40 amino acids and a highly conserved main structure, separated by a variable hinge region. Class II chitinases include PR-P and PR-Q and lack the $\mathrm{N}$-terminal cysteine-rich domain but have a high amino acid sequence identity to the main structure of class I chitinases [130, 225, 226]. In contrast, class III chitinases of tobacco have no similarity with class I and class II but are very similar to a cucumber chitinase having lysozyme activity [131-133].

Like for glucanases, chitinase structures appear very conserved in the plant kingdom. This was evidenced by serological studies $[48,94-97,134,135]$ and from comparison of the decoded cDNA or gene sequences (for reviews see [117, 123]). Thus, class I, class II and class III chitinases have been found in various plant species. Recent studies have shown that a short C-terminal extension of a few amino acids in a tobacco class I chitinase was both necessary and sufficient for vacuolar localization [136]. Such sequences are also found in other vacuolar chitinases from tobacco, bean, potato, poplar and Arabidopsis [74, 137-140] and these chitinases are designated as class Ia to distinguish them from class Ib found in Brassica napus, pea, rice and barley [123, 141-143] and lacking this C-terminal extension, suggesting extracellular localization. In tobacco, chi 28 has an N-terminal sequence identical to chi 32 and chi 34 (Stintzi et al, unpublished); it is extracellular since it probably lacks also the C-terminal end present in chi 32 and chi 34.

A fourth distinct class of chitinases, class IV, still not detected in tobacco, has been proposed to include chitinases present in sugar beet, rape and bean [123, 144]. These class IV chitinases contain a cysteine-rich domain and a conserved main structure which are similar to those of class I chitinases but smaller due to several deletions.

\section{The antimicrobial activities of glycanhydrolases of groups PR-2 and PR-3}

It was suggested already in 1971 [145] that chitinases and 1,3- $\beta$-glucanases may function as a defense against fungal pathogens, but support for this suggestion came much later when several plant chitinases were purified to homogeneity and shown to digest cell walls of pathogenic fungi $[70,146]$ and when some of the extracellularly targeted PR-proteins were found to possess chitinase [92] or 1,3- $\beta$-glucanase [91] activity.

Direct antimicrobial activity of chitinases and $1,3-\beta-$ glucanases

Antifungal activities in vitro of plant chitinases and $1,3-\beta$-glucanases have been studied with various bioassays (for reviews see [116, 147]). Antifungal activity' of plant chitinases was first shown in a bioassay on agar plates with a saprophyte, Trichoderma viride [148]. A similar bioassay was used by several groups to demonstrate a significant inhibition of growth of rapidly growing saprophytes $[124,134,149]$, but the results were rather disappointing with a number of phytopathogenic fungi examined, with some exceptions [150]. Using a modification of this bioassay with small filter disks laid on the agar and enzyme solutions applied to the disks it was shown that chitinases and 1,3- 3 -glucanases purified from elicited pea pods, taken individually, were inhibitory only in exceptional cases to fungal growth around the filter disks [151]. But combinations of the two purified enzymes inhibited growth of most of the fungi studied and more or less mimicked the antif ungal activity observed with the crude pea pod extracts [151]. Using a bioassay in microtiter plates that allows to observe the growth of fungi in liquid media and the same plant hydrolases, it was found that inhibition of growth of Nectria haematococca was only transient [152], suggesting that the fungus apparently had the capacity to adapt to the chitinases and the 1,3- $\beta$-glucanases in its growth medium. However, the bioassay confirmed the synergistic effects of chitinase and 1,3- $\beta$-glucanase, that were also found for several of the tobacco hydrolases $[153,154]$. A detailed analysis of the in vitro antifungal activities of individual hydrolases and of various combinations was made. Class I chitinases (table III) and class I glucanase (table 11) were the most active in the lysis of hyphal tips and in inhibiting the growth of Fusarium solani germlings. The class il isoforms had no effect if assayed individually. This again underlines the striking differences in substrate 
specificity between glucanases (for instance PR-O and gluc $b$ of table II) even if they exhibit similar capacities of hydrolysing laminarin. Furthermore, class II chitinases showed limited inhibitory activity in any combination. Finally the most efficient system was shown to be a combination of class I chitinases and class I glucanases that provided strong synergistic effects. Synergistic antifungal activities were also observed for combinations of basic chitinases and basic glucanases purified from sugar beet and assayed against Trichoderma viride and Cercospora beticola [155]. Since chitin and 1,3- $\beta$-glucan fibres are synthesized simultaneously in the apex of growing hyphae of filamentous fungi, and since these polysaccharides may cross-link and be overlaid with other material in cell wall distant from the apex, these results observed in vitro are not really surprising: nascent chitin of the hyphal apex is the most accessible to hydrolysis by chitinase [123] and the effectiveness of a hydrolase may depend on the simultaneous action of another one to hydrolyse mixed chitin-glucan fibres.

What about antimicrobial activity in vivo of glycanhydrolases? First there are several lines of evidence obtained from immunocytochemical approaches that hydrolases are indeed produced in the vicinity of infection sites and accumulate around fungal cell walls in planta [156-158]. Furthermore, there is generally a spatio-temporal regulation so that glucanases and chitinases are produced simultaneously at the same sites, suggesting that synergistic effects required for optimal antifungal activity in vitro are likely to occur in viv'o.

Since many chitinase and 1,3- $\beta$-glucanase cDNAs or genes have been cloned, the prospects for genetically engineering plants with improved resistince by trinsformation with chitinase or/and glucanase genes are reasonably good, and this approach is now being utilized in many laboratories all over the world (for reviews see [159, 160]). Several successful cases have already been reported. Tobacco and canola plants constitutively expressing high levels of a class I bean chitinase were more resistant against the root pathogen, Rhizoctomia solani [150, 161], whose sensitivity in vitro to this chitinase was well documented by an immunocytochemical approach showing a progressive breakdown of labelled chitin [162]. Transgenic tobacco expressing high levels of either the tobacco class I basic chitinase, the tobacco acidic class III chitinase or the cucumber class III chitinase showed significant resistance against disease caused by Rhizoc'onia solani [38]. Reduction in disease symptoms ciused by the same fungus was also reported in transgenic tobacco constitutively expressing a chitinase of bacterial origin [163]. In contrast, Nicotiana sylvestris transgenic plants expressing high levels of the tobacco class I chitinase showed unaltered susceptibility to the leaf pathogen, Cercospora nicotianae. It is possible that the highly expressed chitinase, since it is located intracellularly, did not come to contact with the intercellular developing fungus. Since many fungi grow intercellularly, the manipulated enzymes should be targeted to the extracellular spaces. Such attempts are already under way, and the most potent antifungal tobacco hydrolases of class I have been modified at their C-terminus to be targeted to the extracellular spaces of transgenic plants. It was found [153] that the extracellular washing fluids indeed contained the modified proteins that had retained full antifungal activity when assayed individually in vitro and their synergistic potential when used in combination. Experiments are now in progress to see whether targeting of the tobacco class I hydrolases to the extracellular space is an effective way of increasing fungal resistance. There is an example, however, that removal of the targeting sequence of the class I tobacco chitinase suppressed resistance against Rhizoctonia solani in transgenic plants [164]. There is also a report of an antibacterial resistance obtained in transgenic potato expressing constitutively phage $\mathrm{T} 4$ lysozyme [165]. It will be interesting to test antibacterial resistance by constitutive expression of plant lysozyme genes, for instance those of class III chitinases-lysozymes.

In conclusion, direct antifungal activities of plant chitinases and 1,3- $\beta$-glucanases have been clearly demonstrated with various bioassays. It is very likely that plants use induction of these hydrolases as an efiicient defense response. Further results obtained from transgenic plants expressing high constitutive levels of hydrolases have to be awaited before it can be concluded that the strategy is valuable and mimics, at least partially, a pathogen-induced defense response. In this respect, the observations in [152] are important showing that in vitro fungi are onty temporarily inhibited by chitinases and 1,3- $\beta$-glucanases and can adapt to even high levels of these hydrolases. Thus, a constitutively expressed high level may not be very effective in genetically-engineered defense, and it would be preferable to increase their levels suddenly in the vicinity of approaching hyphae. In natural induced defense, such as the hypersensitive reaction, levels of hydrolases are highly induced within a short time and operate in two successive lines: a first line of extracellularly-targeted enzymes and a second line of the vacuolar and very active enzymes released during hypersensitive cell death and collapse [71].

\section{Indirect antimicrobial activity of chitinases and glu- canases}

It has been known for some time that plant chitinases and 1,3- $\beta$-glucanases have a potential to partially 
degrade fungal cell walls $[70,146,151]$. The products released are oligosaccharides, some of which have been shown to be perceived by the plant cell as signals, so-called 'elicitors', and to induce active defense responses in the absence of any infection (for reviews see $[16,167,168])$. Indeed, chitin and chitosan oligomers and 1,3- $\beta$-glucans with some branching have been shown to induce a set of metabolic alterations typical of defense responses [16, 167-171]. The biologically active oligochitins and oligochitosans are thought to be released during the plantpathogen interaction by the action of plant chitinases and chitosanases $[168,170]$. This might lead to an amplification of the defense responses, some of the induced proteins being again chitinases [171]. Concerning the occurrence and activity of glucan elicitors (for a review see [167]), many cases have probably to be re-examined since the discovery that the activity of fungal elicitor fractions believed to contain mainly glucans was due to proteinaceous or glycoprotein elicitors [172-175, 227]. Indeed the elicitors active on soybean are glucans derived from the fungal cell wall and their structure has been clearly established [176, 177]. It has also been shown that soybean endo-1,3- $\beta$ glucanases were indeed able to release elicitor active fragments from the fungal cell wall [122,178-180].

In conclusion, plant chitinases and 1,3- $\beta$-glucanases are likely to play a dual role: they are directly antimicrobial by hydrolysing structural components of the cell wall of microbes, furthermore they are also indirectly antimicrobial by releasing oligosaccharides that are active elicitors of defense responses and, in turn, may be responsible for the amplification of the defense responses [10, 18, 167].

\section{The PR-4 group}

In tobacco four proteins of the PR-4 group have been isolated from TMV-infected leaves and named $r 1, r 2$, sl, s2 [181]. They are all acidic proteins (table IV), with yet no known basic counterpart, and migrate on

Table IV. The tobacco PR-4 group: 'win-like' proteins. The proteins were isolated according to [181]. For all other items, see legend to table i.

\begin{tabular}{ccccc}
\hline Name & $\begin{array}{c}\text { Molecular } \\
\text { mass } \\
(k D a)\end{array}$ & $\begin{array}{c}\text { Elution } \mathrm{pH} \\
\text { (chromato- } \\
\text { focusing) }\end{array}$ & Localization & $\begin{array}{c}\text { Biological } \\
\text { activity }\end{array}$ \\
\hline r2 & 13 & 7.0 & ext & $?$ \\
r1 & 14.5 & 7.0 & ext & $?$ \\
s2 & 13 & 7.4 & ext & $?$ \\
s1 & 14.5 & 7.4 & ext & $?$ \\
\hline
\end{tabular}

the native basic gel system (see fig 1 ) in the vicinity of acidic PRs-5. In fact the couples $\mathrm{rl} / \mathrm{r} 2, \mathrm{sl} / \mathrm{s} 2$ migrate close to PR-R and PR-S, respectively. However, in denaturing gels, PRs of group 4 migrate as small $13-14.5-\mathrm{kDa}$ proteins and are clearly distinguishable from other PRs [181]. They all are extracellular and serologically related to each other but do not show a serological relationship to other PRs or PR-groups. Primary structure deduced from cDNA clones is known for two of these proteins $[182,183]$ and indicates $50 \%$ sequence similarity to Winl and Win2 that are induced in potato in response to wounding. They show also significant similarity to the C-terminal sequence of hevein, a protein from latex of Hevea brasiliensis. Nothing is known about the biological function or activity of these proteins which have not been studied extensively. They represent also the less ubiquitous of the five PR-groups since only one similar protein has been described so far, a 15-kDa tomato protein [184].

\section{The PR-5 group: 'thaumatin-like' proteins}

In tobacco Samsun NN this group includes two almost neutral proteins named $R$ and $S$ (table $V$ ). These extracellular proteins were among the 10 initially detected on the native basic gel system [24] and we demonstrated $[90,181]$ that they belonged to a distinct serological group (see also fig 1). They correspond probably to proteins R-minor and R-major found by others [185] in the cultivar Xanthi nc of Nicotiana tabacum. Two basic serologically-related counterparts which accumulate also in infected leaves (table V) have been identitied as osmotins $[67,186]$. Osmotin had been previously found to accumulate in tobacco cells in response to salt stress [187]. The basic proteins of group PR-5 are localized in the vacuolar compartment $[67,187]$ whereas the slightly acidic-neutral members $R$ and $S$ are apoplastic [188, 189]. cDNAs have been cloned which correspond to acidic $\mid 190$, 191] and basic [192] tobacco PRs-5. There is more

Table V. The tobacco PR-5 group: 'thaumatin-like' proteins. The proteins were isolated as described in $[181,186]$. For all other items, see legend to table 1.

\begin{tabular}{c|cccc}
\hline Name & $\begin{array}{c}\text { Molecular } \\
\text { mass } \\
(k D a)\end{array}$ & $\begin{array}{c}\text { Elution pH } \\
\text { (chromato- } \\
\text { focusing) }\end{array}$ & Localization & $\begin{array}{c}\text { Biological } \\
\text { activity }\end{array}$ \\
\hline R & 24 & 6.9 & ext & $?$ \\
\hline S & 24 & 7.5 & ext & antifungal \\
\cline { 1 - 1 } n-osmotin & 22 & $>7$ & int & $?$ \\
\cline { 1 - 1 } osmotin & 22 & $>7$ & int & antifungal \\
\hline
\end{tabular}


Table VI. Anti-f ungal activity of PR-5 proteins estimated from inhibition of spore gennination (S) or of hyphal growth $(\mathrm{H})$.

\begin{tabular}{|c|c|c|c|c|}
\hline \multirow[t]{2}{*}{ Proteins } & \multicolumn{2}{|c|}{ Fungus } & \multirow[t]{2}{*}{ Effects } & \multirow[t]{2}{*}{ References } \\
\hline & Genus/species & Class & & \\
\hline Osmotin (tobacco) & $\begin{array}{l}\text { Phytophthora infestans } \\
\text { Candida albicans } \\
\text { Neurospora crassa } \\
\text { Trichoderma reesei }\end{array}$ & $\begin{array}{l}\text { Oomycetes } \\
\text { Hyphomycetes } \\
\text { Ascomycetes } \\
\text { Hyphomycetes }\end{array}$ & $\begin{array}{l}S \\
S \\
S \\
S\end{array}$ & $\begin{array}{l}{[200]} \\
{[209]} \\
{[209]} \\
{[209]}\end{array}$ \\
\hline PR-S (tobacco) & Cercospora beticola & Hyphomycetes & $\mathbf{H}$ & [209] \\
\hline AP 24 (tomato) & Phyrophthora infestans & Oomycetes & $\mathbf{S}$ & {$[200]$} \\
\hline Thaumatin ( $T$ daniellii) & Candida albicans & Hyphomycetes & $\mathbf{H}$ & [199] \\
\hline Zeamatin (com) & $\begin{array}{l}\text { Candida albicans } \\
\text { Tirichoderma reesei } \\
\text { Neurospora crassa } \\
\text { Fusarium oryspor:ym } \\
\text { Alternuria solani }\end{array}$ & $\begin{array}{l}\text { Hyphomycetes } \\
\text { Hyphomycetes } \\
\text { Ascomycetes } \\
\text { Hyphomycetes } \\
\text { Ascomycetes }\end{array}$ & $\begin{array}{l}\mathbf{S} \\
\mathbf{S} \\
\mathbf{S} \\
\mathbf{H} \\
\mathbf{H}\end{array}$ & 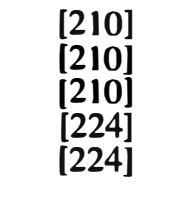 \\
\hline Trimatin (wheat) & $\begin{array}{l}\text { Candida albicans } \\
\text { Trichoderma reesei } \\
\text { Newrospora crassa }\end{array}$ & $\begin{array}{l}\text { Hyphomycetes } \\
\text { Hyphomycetes } \\
\text { Ascomycetes }\end{array}$ & $\begin{array}{c}\mathrm{S} \\
\mathrm{H}, \mathrm{S} \\
\mathrm{H}, \mathrm{S}\end{array}$ & $\begin{array}{l}{[199]} \\
{[199]} \\
{[199]}\end{array}$ \\
\hline Protein R (barley) & $\begin{array}{l}\text { Candida albicans } \\
\text { Trichoderma viride } \\
\text { Fusarium oxysporum }\end{array}$ & $\begin{array}{l}\text { Hyphomycetes } \\
\text { Hyphomycetes } \\
\text { Hyphomycetes }\end{array}$ & $\begin{array}{l}\mathbf{S} \\
\mathbf{S} \\
\mathbf{S}\end{array}$ & $\begin{array}{l}{[197]} \\
{[197]} \\
{[197]}\end{array}$ \\
\hline Protein S (barley) & $\begin{array}{l}\text { Cundida albicans } \\
\text { Tricherderma viride } \\
\text { Fusarium orysporum }\end{array}$ & $\begin{array}{l}\text { Hyphomycetes } \\
\text { Hyphomycetes } \\
\text { Hyphomycetes }\end{array}$ & $\begin{array}{l}\mathbf{S} \\
\mathbf{S} \\
\mathbf{S}\end{array}$ & $\begin{array}{l}{[197]} \\
{[197]} \\
{[197]}\end{array}$ \\
\hline
\end{tabular}

than $90 \%$ sequence identily between PR-R and PR-S and mu:e than $60 \%$ between the acidic and the basic counterparts. There is also $60 \%$ sequence similarity between the acidic PRs-5 and thaumatin, a sweet-tasting protein extracted firom the africin shrub, Thairmancicoccus daniclli: therefore, the proteins of group PR-5 are also called the 'thaumatin-like PRs'. Thaumatin-like proteins have now been characterized from various plant species [193-201]. Genes encoding acidic and basic forms of tobacco PR-5 proteins have been isolated [202, 203] and do not contain introns. At least two domains of the promoter are involved in the induction of acidic PR-5 upon TMV infection [204]. For basic PR-5 a study of tissue-specific expression indicates high expression in roots and stems and a possible involvement of abscisic acid in promoter activation during the response to salt stress. cDNAs encoding PRs-5 from several other plant species have been cloned [54, 197, 205-208].

Concerning the search for a possible biological activity of proteins of the PR-5 group, the first attempts were based on sequence similarity to a bifunctional inhibitor of maize, an inhibitor of both trypsin and insect $\alpha$-amylase [193]. We did not find this bifunctional activity in any of the isolated tobacco proteins of table $\mathrm{V}$, and it is noteworthy that this activity has also not be reported for any of the numerous thaumatin-like proteins isolated by others (see table VI), including the maize protein zeamatin $[199,209]$ that was found highly similar, if not identical, to the maize bifunctional inhibitor (Selitrennikoff, personal communication). Transgenic plants expressing constitutively acidic PR-5 were not protected from eating by Spodoptera exiga and $H$ virescens larvae, as well as not being more resistant to infection by TMV [113].

The first report on biological activity of a PR-5 protein was the demonstration that zeamatin, a protein from maize, was antifungal with membrane permeabilizing activity [210]. Other cereals apparently contained related proteins with similar antifungal activity [199]. Then another group found that tobacco osmotin and the tomato analog was active against Phytophthora infestans, responsible for late blight disease of potato [200]. We confirmed and extended these results by showing that several members of the PR-5 group had differential antifungal activities with 
specificity for different fungal species [209]. There are now many lines of evidence that proteins of the PR-5 group from various plant species have direct antifungal activity against several classes of fungi (table VI). They have been shown to inhibit hyphal growth and mediate hyphal and spore lysis in in vitro assays [197, 199, 200, 209, 210]. It has been proposed that the antifungal activity of the maize PR-5, zeamatin, is the result of permeabilization of fungal membranes [210] through a mechanism that is still operative at $4^{\circ} \mathrm{C}$. This capacity may be related to formation of amphipathic domains resulting from secondary structure mediated by disulfide linkages analogous to another type of plant defense proteins, thionins [211]. These amphipathic domains interact with membranes resulting in pore or channel formation, and in extreme conditions membrane lysis.

More information has to be obtained on the molecular mechanisms of antifungal activity of PRs-5. If the effects on fungal membrane permeabilization were confirmed, then a combination of an hydrolytic enzyme of group PR-2 or PR-3 and a PR-5 protein expressed constitutively by genetic engineering would be very likely to confer a high level of protection against infection by fungi, since the two types of proteins would be acting on two different and essential targets of the pathogen.

\section{Other tobacco PR-proteins}

Several tobacco PRs have been characterized recently which cannot be classified into the five major groups (table VII).

We have isolated a 45-kDa basic protein [90] which cross-reacts with antisera raised against proteins of groups PR-2, PR-3 and PR-5 (Stintzi, unpublished). The significance of these observations is not under- stood yet, since the antibodies used have been shown to be very specific to proteins of the corresponding groups in tobacco $[67,91,92,181,186]$ or in other plant species [97, 135, 212], and no hydrolase activity has been found associated to the purified protein even by using very sensitive enzymatic assays. cDNA cloning is presently in progress.

Another basic protein with a molecular mass of $16 \mathrm{kDa}$ has been found to accumulate in TMVinfected tobacco leaves and its biological activity is also unknown. It does not cross-react with antibodies raised against the acidic PRs-1 (-la, $-1 \mathrm{~b}$ and $-1 \mathrm{c})$ or against the basic counterpart PR-lg (table I). These data and partial microsequencing demonstrate that it does not belong to the PR-1 group in spite of a similar molecular mass. It is presently under investigation.

Two $\alpha$-amylases are strongly induced in tobacco leaves upon infection by TMV [213]. They are endotype enzymes and iave many features in common with other typical acidic PRs, for instance an apoplastic localization and a high degree of resistance to proteolytic cleavage. Both proteins have an apparent molecular mass of 44-kDa. Like glycanhydrolases of groups PR-2 and PR-3 they can be considered as direct antifungal enzymes since their substrates, 1,4$\alpha$-glucans, occur in the cell wall of many fungi.

We have also shown a strong induction of a proteinase inhibitory activity in tobacco during the hypersensitive reaction to TMV [214]. The active inhibitor was purified and shown to be a small polypeptide of the inhibitor I type which displays a strict specificity for serine proteinases of microbial origin, such as subtilisin or proteinase $\mathrm{K}$. Thus, the tobacso inhibitor appears as a good candidate for reducing proteolytic activities of phytopathogenic bacteria or fungi in planta. It is noteworthy that the active inhibitors are not monomers, in contrast with most of the other PRs.

Table VII. Other not yet classified tobacco PR-proteins. Protcins T!M!Pa and TIMPb, amyl 1 and amyl 2, 45 K and $16 \mathrm{~K}$, were isolated and assayed as described in [214, 215], [213], [90], respectively. Proteins P39a and P40a have been isolated recently by the authors (unpublished results) and partial amino acid sequencing has shown identity to a cloned tobacco peroxidase [218]. For all other items, see legend to table I.

\begin{tabular}{ccccc}
\hline Name & $\begin{array}{c}\text { Molecular } \\
\text { mass }(k D a)\end{array}$ & $\begin{array}{c}\text { Isoelectric } \\
\text { point }\end{array}$ & localization & $\begin{array}{c}\text { Biological } \\
\text { activity }\end{array}$ \\
\hline TIMPa & 8 & 8.7 & int & inhibitors of \\
TIMPb & 8 & 8.7 & int & microbial proteases \\
P39a & 39 & $<7$ & ext & peroxidase \\
P40a & 40 & $<7$ & ext & peroxidase \\
amyl 1 & 44 & 4.5 & ext & $\alpha$-amylase \\
amyl 2 & 44 & 4.2 & ext & $\alpha$-amylase \\
$45 \mathrm{~K}$ & 45 & $>7$ & ext & $?$ \\
16K & 16 & $>7$ & nd & $?$ \\
\hline
\end{tabular}


Two closely related cDNAs were cloned recently and shown to encode two active inhibitors whose subunits were separated by HPLC [215]. Southem analysis of genomic DNA. comparison of deduced ammo acid sequences and characterization of the two separated proteins (TIMPa and TIMPb, table VII) suggest that the two genes of tobacco are homeologues origmatmg from each parent. We have shown the presence of a glutamic acid residue at the $\mathrm{Pl}$ position of the active site, known to determine the specificity of this type of inhibitors. However. the V8 proteinase from Staphylococcus aureus, an enzyme that cleaves polypeptides after glutamic residues was not affected by the tobacco inhibitor. We have demonstrated a strong accumulation of both mRNAs and proteins in response to TMV, messengers and products of the two genes being present in a 3/2 ratio in infected leaves as w'ell as in the upper uninfected leaves, the induction being markedly lower, however, at distance from the infection sites. We found that the transcripts also accumulated in sepals and petals of healthy plants, indicating that these genes are developmentally regulated. Unlike the tomato and potato I inhibitors [216], the tobacco inhibitor was only weakly induced by wounding, but was expressed upon treatment with salicylic acid and ethylene, like many other PR-proteins.

We have also isolated two acidic extracellular proteins with peroxidase activity. Peroxidase isozyme induction by TMV infection of tobacco had been studied by others $\mid 217]$ and indicated a preferential induction of two moderately anionic peroxidases called P56 and P61, whereas the anionic isozymes P35 and P37 were already present in uninfected material and only weakly induced during iufection. In fact the isoforins P39: and P40a that we have isolated are strongly induced in TMV-infected Samsun NN (Stintzi, unpublished). Surprisingly, partial amino acid sequence analysis indicates identity to P35 whose cDNA has been cloned $[218$ ] and which has been described as a lignin-forming enzyme, based on its high expression in the lignitied stem and on its affinity for coniferyl alcohol. In our group we are also studying the induction of aromatic metabolism around the virus lesions and already have evidence for an increased incorporation of phenolics into the cell wall $[219,220]$ that is perhaps catalysed by P39a and P40a. Further studies on these peroxidases are inder way to understand their function and role in defense.

\section{Conclusion}

This special issue is dedicated to Professor Léon Hirth who initiated part of the work described above and encouraged thrce of us, $\mathrm{P}$ Geoffroy, $M$ Legrand and B Fritig already in the early 1970s to develop a research project on the response of plants to exposure to pathogens, namely his favourite pathogens, viruses. Endowed with an outstanding scientific intuition, he suggested already at that time that the hypersensitive response to viruses would be a particularly good model to study.

In fact the hypersensitive response (HR) of plants to pathogens is one of the most efficient natural mechanisms of induced defense of plants against pathogens. This is also true in the case of virus infections, viruses being the inducers in our model system. In hypersensitivity to viruses the same characteristics are found as in incompatible interactions between plants and fungi or bacteria $[9,10]$ : i) necrosis at and around each point at which the leaf tissue was infected; ii) localization of the pathogen to the region of each initiated infection; and iii) induction of marked metabolic changes in the cells surrounding the necrotic area, these changes being believed to cause, or at least to contribute to, the resistance observed. Furthermore, the hypersensitive response to viruses involves a cascade of events and signals [18] similar to that proposed for active defense against fungi and bacteria: the response would be initiated by a specific gene-for-gene recognition between the plant and the virus that would lead to cell damage (death of a number of cells) and the release of intermediary signals which in tum would enter a reception-transduction pathway leading to major changes in gene expression (usually gene activation) responsible for the resistance observed.

Under at first the tutelage of Prof essor Hirth and later his support through stimulating discussions and encouragements, our group has studied particularly the downstream part of this cascade, ie the changes in host gene expression and their possible contribution to the defense response. For some time we have invested efforts to understand the role of plant phenolics in disense resistance, and these efforts are still continuing with some focus on the role of cell wall bound phenolics [221]. However, since 1985, major emphasis has been put on a group of strongly induced proteins with typical properties, the PR-proteins also referred to as 'stress proteins'. Tobacco responding hypersensitively to TMV proved to be a particularly useful experimental system, as anticipated by Professor Léon Hirth, and this model is still recognized as the prototype system from which we have characterized biochemically the highest number and widest array of PRs. Among the 33 proteins isolated, 31 have been characterized and 25 fall into five groups of ubiquitous proteins. We have identified the enzymatic activities and functions of proteins of groups PR-2 and PR-3 as the hydrolytic erzymes $1,3-\beta$-glucanases and chitinases-lysozymes, respectively. We have also participated in the discovery that PR-5 proteins had antifungal activity, and presently, are participating in a 
collaborative work aiming to study the antifungal properties of proteins of group PR-1, the initially discovered group of PRs $[1,2]$. The PR-4 group is still without known biological activity. Other proteins characterized in tobacco are the hydrolases $\alpha$-amylases, inhibitors of microbial proteases, and peroxidases. With the exception of the latter, all activities characterized appear to be direct antimicrobial activities (antifungal and/or antibacterial). Some of the proteins also exhibit indirect antimicrobial activities, for instance the elicitor-releasing hydrolases and peroxidases that are likely to catalyse cell wall cross-linking of phenolics.

Very surprisingly, none of the characterized proteins appears to have direct antiviral activity, even though all of them are induced in response to the virus and this response obviously includes the induction of an antiviral state that finally localizes the virus. It has been reported that two antiviral proteins called gp35 and gp22 were purified from tobacco and characterized by monoclonal antibodies to human $\beta$-interferon [222]. Later it was shown [223] that gp35 corresponded to the basic, vacuolar form of $1,3-\beta$-gluaanase (gluc b of table II) and gp22 was related to both the acidic and basic forms of PR-5 from tobacco. We have tested gluc b (table II) and osmotin (table V) using exactly the bioassay of reference [222] and could not find any antiviral activity associated to these proteins. In fact the bioassay itself is not really representative of what happens in hypersensitively-induced resistance to the virus. The mechanism to be unravelled is not an inhibition of establishment of virus infection, but rather a mechanism responsible for inhibition of virus spread. This mechanism might rely on yet undetected component(s), it might also result from the wide range and superposition of metabolic alterations, for instance the cell wall thickening that could affect the viral 'movement' proteins(s).

As described above, the prospects for geneticallyengineered plants with improved resistance against fungi and bacteria by transformation with PR genes are promising, especially if combinations of PRs are expressed with potential synergistic effects or with different target components in the microbe. This still does mimic only partially natural defense which involves a wide array of direct and indirect antimicrobial compounds. The natural defense system could be better approached by manipulating the signals that trigger a battery of defense components, and the characterization of such signals and their manipulation is now under study in many laboratories all over the world.

\section{Acknowledgments}

The authors are indebted to D Bersuder and I Genetet for their contribution to the isolation of some of the PR-proteins and express their thanks to $\mathrm{J}$ Vonesch for typing the manuscript.

\section{References}

1 Gianinazzi S, Martin C, Vallée JC. (1970) Hypersensibilité aux virus, température et protéines solubles chez le Nicotiana Xambi nc. Apparition de nouvelles macromolécules lors de la répression de la synthèse virale. $C R$ Acad Sci Paris 270, serie D, 2383-2386

2 Van Loon LC, Van Kammen A (1970) Polyacrylamide disc electrophoresis of the soluble leaf proteins from Nicotiana rabacum var 'Samsun' and 'Samsun NN'. Changes in protein constitution after infection with TMV. Virology 40, 199-21]

3 Flor AH (1942) Inheritance of pathogenicity in Melampsora lini. Phytopathology 32, 653-669

4 Ellingboe $\mathrm{HH}$ (1981) Changing concepts in hostpathogen genetics. Annu Rev Phytoparhol 19, 125-143

5 Ellingboe AH (1982) Genetical aspects of active defence. In: Active Defense Mechanisms in Plants (Wood RKS, ed), NATO ASI Series, Plenum Press, New York and London, 179-192

6 Crute IR (1985) The genetic bases of relationships between microbial parasites and their hosts. In: Mechanisms of Resistance to Plant Diseases (Fraser RSS, ed), Martinus Nijhoff/Dr W Junk Publishers, Dordrecht, 80142

7 Keen NT (1990) Gene-for-gene complementarity in plantpathogen interactions. Annu Rev Genet 24, 447-463

8 De Wit PJGM (1992) Molecular characterization of genefor-gene systems in plant-fungus interactions and the application of avirulence genes in control of plant pathogens. Annu Rev Phytopathol 30, 391-418

9 Keen NT (1992) The molecular biology of disease resistance. Plant Mol Biol 19, 109-122

10 Lamb CJ, Lawton MA, Dron M, Dixon RA (1989) Signals and transduction mechanisms for activation of plant defenses against microbial attack. Cell 56, 215-224

11 Fritig B, Legrand M, Hirth L (1972) Changes in the metabolism of phenolic compounds during the hypersensitive ieaction of tobacco to TMV. Virology 47, 845-848

12 Legrand M, Fritig B, Hirth L (1976) Emzymes of the phenylpropanoid pathway and the necrotic reaction of hypersensitive tobacco to tobacco mosaic virus. Phytochemistry 15, 1353-1359

13 Legrand M (1983) Phenylpropanoid inetabolism and its regulation in disease. III: Biochentical Plant Pathology' (Callow JA, ed), Wiley, Chichester, 367-384

14 Bailey JIA, Mansfield JW (1982) Phytualexins. Blackie, Glasgow and London

15 Dixon RA, Dey PM. Lamb CJ (1983) Phytoalexins: Enzymology and molecular biology. Adv Enzymol .55, 1-. 136

16 Darvill AG, Albersheim P (1984) Thytoalexins and their elicitors-a defense againsi microbial infection in plants. Amru Rev Plant Pliysiol 35. 243-275

17 Ebel J (1986) Phytoalexin synthesis: the biochemical analysis of the induction process. Ammu Rev Phyroparhol 24, 235-264

18 Fritig B, Kauffmann S, Dumas B, Geoffroy P, Kojp M. Legrand $M$ (1987) Mechanism of the hypersensitive reaction of plants. In: Plant Resistance to Viruses (Evered D. Hamett S, eds), Ciba Found Symp 133, Wiley and Sons, Chichester, 92-108

19 Collinge DB, Slusarenko AJ (1987) Plant gene expression in response to pathogens. Plant Mol Biol 9. 389-410

20 Bradley DJ, Kjellbom P, Lamb CJ (1992) Elicitor- and wound-induced oxidative cross-linking of a proline-rich 
plant cell wall protein: A novel, rapid defense response. Cell 70. 21-30

21 Vamer JE. Lin LS (1989) Plant cell wall architecture. Coll 56. 231-239

22 Vanse CP. Kirk TK. Shervood RT (1980) Lignification as a mechanism of disease resistance. Anm! Rev Phytopathol 18, 259-288

2.3 Matem U. Kneusel RE (1988) Phenolic compounds in plant disease resistance. Phitonarasitica 16, 153-170

24 Van Loon L.C (1982) Regulation of changes in proteins and enzymes associated with active defence against virus infection. In: Acrive Defense Mechanisms in Plants (Wood RKS. ed). Plenum Press, London, 37, 247-273

25 Jamet E. Kopp M, Fritig B (1985) The pathogenesisrelated proteins of tobacco: their labelling from $\left.\left.\right|^{14} \mathrm{C}\right]$ amino acids in leaves reacting hypersensitively to inf ection by tobacco mosaic virus. Physiol Plant Pathol 27. 29-41

26 Van Loon LC ( 1985) Pathogenesis-related proteins. Plant Mol Biol 4, 111-116

27 Jamet E, Fritig B (1986) Purification and characterization of 8 of the pathogenesis-related proteins in tobacco leaves reacting hypersensitively to tobacco mosaic virus. Plant Mol Biol 6. 69-80

28 Pierpoint WS (1986) The pathogenesis-related proteins of tobacco leaves. Phyrocininistry 25. 1595-1601

29 Van Loon LC, Gerritsen YAM, Ritter CE (1987) Identification. purilication, and characterization of pathogenesisrelated proteins from virus-intected Samsun NN tobacco leaves. Plant Mol Biol 9, 593-609

30 Ross AF (196I) Systemic acquired resistance induced by localized virus infection in plants. Virology 14, 340 358

31 Ross AF (1966) Systemic effiects of local lesion formaltion. III: Virusse's of Plants (Beemster ABR. Dijkstra J, eds), North-Holland Publishing Company, Amsterdam. 127-150

32 Locbensteill Ci (1972) Loculization ind induced resistance in virus-infiected plants. Almur Rev Phivtopathol 10. 177-2()6

33 Meintyre .JL. Dodds JA ( 1979) Incluction of locilized and

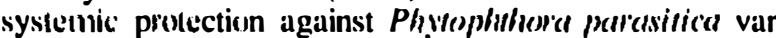
nicestiesuese by tobacco mosaic virus inlisction of tobacco hypersensitive to the virus. Phyisiol Plant Pathol 15. $321-.330$

34 Ahl P. Benjanıi A. Simson R, Gianinazzi S (1981) Induction chez le tabac par Psesudomonas syringac' de nouvelles protênes (protésines ' $b$ ') associées au développement d'une rísistance non spécitique à une deuxième infection. Phiresputhol Z 102, 2(1)-212

35 Bergstrom C.C. Jolinson MC, Kuc J (1982) Effects of locill infection of cucumber by Collefortricherm logena. ritum. Psenelomomas lachrymans or tobacco necrosis virus on systemic resistance to cucumber mosaic virus. Phytopestulo.g. 72, 922-926

36 McIntyre JL, Dodds JA, Hare JD (1981) Effects of localized infections of Nicoticana tabac'um by tobacco mosaic virus on systemic resistance against diverse pathogens and an insect. Plyvepalholog! 71. 297-301

37 Ye XS. Pan SQ. Kuc J (1989) Pathogenesis-related proteins and systemic resistance to blue mold and tobacco mosaic virus induced by tobacco mosaic virus, $P(\operatorname{rom})(1)-$ sporce cabacina and aspirin. Phusiol Mol Plame Pathol 35, $161-175$

38 Lawton K, Uknes S, Friedrich L. Gaffiney T. Alexander D. Goodman R, Metraux JP, Kessnaann H. Ahl-Goy P, Gut
Rella M, Ward E, Ryals J (1993) The molecular biology of systemic acquired resistance. in: Mechanisms of Plant Defense Responses (Fritig B, Legrand M. eds), Kluwer Academic Publishers, Dordrecht, 422-432

39 Carr JP, Klessig DF (1989) The pathogenesis-related proteins of plants. In: Genetic Engineering: Principles and Methods (Setlow JK, ed), Vol II, Plenum Press, New York, London, 65-109

40 Bol JF, Linthorst HJM, Cornelissen BJC (1990) Plant pathogenesis-related proteins induced by virus infection. Almu Rev Phytopathol 28, 113-138

41 Bowles DJ (1990) Defense-related proteins in higher plants. Anmu Rev Biochem 59, 873-907

42 Linthorst HJM (1991) Pathogenesis-related proteins of plants. Crit Rev Plant Sci 10, 123-150

43 White RF, Antoniw JF (1991) Virus-induced resistance responses in plants. Crit Rev Plant Sci 9, 443-455

44 Ahl P, Gianinazzi S (1982) b-Protein as a constitutive component in highly (TMV) resistant interspecific hybrids of Nicotiana glutinosa $\times$ Nicotiana debneyi. Plant Sci Lett 26, 173-181

45 Dumas E, Gianinazzi S, Cornu A (1987) Genetic aspects of polyacrylic-acid-induced resistance to tobacco mosaic virus and tobacco necrosis virus in Nicotiana plants. Plani Pathol 36, 544-550

46 Asselin A, Grenier J, Coté F (1985) Light-influenced extracellular accumulation of $\boldsymbol{b}$ (pathogenesis-related) proteins in Nicotiana green tissue induced by various chemicals or prolonged floating on water. $C a n J B o t 63$, 1276-1283

47 De Tapia M, Bergman P, Awade A, Burkard G (1986) Analysis of acid extractable bean leaf proteins induced by mercuric chloride treatment and alfalfa mosaic virus infection. Partial purification and characterization. Plamt Sci 45, 167-177

48 Nasser W, De Tapia M, Burkard G (1990) Maize pathogenesis-related proteins: characterization and cellular distribution of $\beta-1,3-$ glucanases and chitinases induced by brome mosaic virus infection or mercuric chloride treatment. Plivisiol Mol Plant Patliol 36, 1-14

49 White RF (1979) Acetylsulicylic acid (aspirin) induces resistance to tobacco mosaic virus in tobacco. Virology 99. 410-412

50 Van de Rhee MD, Van Kan JAL. Gonzales-Jaen MT, Bol JF (1990) Analysis of regulatory elements involved in the induction of two tobacco genes by salicylate treatment and virus infection. Plant Cell 2, 357-366

51 Ward ER, Uknes SJ, Williams SC, Dincher SS, Wiederhold DL, Alexander DC, Ahl Goy P, Metraux JP, Ryals JA (1991) Coordinate gene activity in response to agents that induce systemic acquired resistance. Plant Cell 3 , 1085-1094

52 Yalpani N, Silvennan P, Wilson TMA, Kleier DA, Raskin 1 (1991) Salicylic acid is a systemic signal and an inducer of pathogenesis-related proteins in virus-infected tobacco. Plciin Cell 3, 809-818

53 Malamy J, Klessig DF (1992) Salicylic acid and plant disease resistance. Plant .I 2, 643-654

54 Uknes S, Mauch-Mani B, Moyer M, Potter S, Williams S, Dincher S. Chandler D. Slusarenko A, Ward E, Ryals J (1992) Acquired resistance in Arabidopsis. Plant Cell 4, 645.656

55 Ernst D, Schraudner M, Langebartels C, Sandermann Jr H (1992) Ozone induced changes of mRNA levels of $\beta-1,3-$ glucanase, chitinase and 'pathogenesis-related' protein I b in tobacco plants. Plant Mol Biol 20, 673-682 
56 Didier jean L, Frendo P, Nasser W, Marivet J, Genot G, Margis-Pinheiro M, Passelegue E, Amegninou D, Martin C, Burkard G (1993) Plant genes induced by chemicals and pollutants. In: Mechanisms of Plant Defense Responses (Fritig B, Legrand M, eds) Kluwer Academic Publishers, Dordrecht, 276-285

57 Christ U, Mösinger E (1989) Pathogenesis-related proteins of tomato: I. Induction by Phytophthora infestans and other biotic and abiotic inducers and correlation with resistance. Physiol Mol Plant Pathol 35, 53-65

58 Hughes RK, Dickerson AG (1991) Modulation of elicitor-induced chitinase and $\beta$-1,3-glucanase activity by hormones in Phaseolus vulgaris. Plant Cell Physiol 32, 853-861

59 Van Loon LC (1983) The induction of pathogenesisrelated proteins by pathogens and specific chemicals. Neth J Plant Pathol 89, 265-273

60 Memelink J, Linthorst HJM, Schilperoort RA, Hoge JHC (1990) Tobacco genes encoding acidic and basic isoforms of pathogenesis-related proteins display different expression patterns. Plant Mol Biol 14, 119-126

61 Mohnen D, Shinshi H, Felix G, Meins F (1985) Hormonal regulation of $\beta-1,3$-glucanase messenger RNA levels in cultured tobacco tissues. EMBO J 4, 1631-1635

62 Felix G, Meins Jr F (1986) Developmental and hormonal regulation of $\beta-1,3-$ glucanase in tobacco. Planta 167, 206-211

63 Leguay JJ, Jouanneau JP (1987) Auxin (2,4-dichlorophenoxyacetic acid) starvation and treatment with glucan elicitor isolated from Phytophthora megasperma induces similar responses in soybean-cultured cell suspensions. Develop Genet 8, 351-364

64 Shinshi H, Mohnen D. Meins F (1987) Regulation of a plant pathogenesis-related enzyme: inhibition of chitinase and chitinase mRNA accumulation in cultured tobacco tissues by auxin and cytokinin. Proc Natl Acad Sci USA 84, 89-93

65 Sauter M, Hager A (1989) The mycorrhizal fungus Amanita muscaria induces chitinase activity in roots and in suspension-cultured cells of its host Picea abies. Planta $179,61--66$

66 King GJ, Hussey CE, Turner VA (1986) A protein induced by $\mathrm{NaCl}$ in suspension cultures of Nicotiana labacum accumulates in whole plant roots. Plant Mol Biol 7, 441-449

67 Grosset J, Meyer Y, Chartier Y, Kauffmann S, Legrand M, Fritig B (1990) Tobacco mesophyll protoplasts synthesize $1,3-\beta$ glucanase, chitinases, and 'osmotins' during in vitio culture. Plant Physiol 92, 520-527

68 Nelson DE, Raghothama KG, Singh NK, Hasegawa PM, Bressan RA (1992) Analysis of structure and transcrip tional activation of an osmotin gene. Plant Mol Biol 19, 5i7-588

69 Van Loon LC (1977) Induction by 2-chloroethylphosphonic acid of viral-like lesions, associated proteins, and systemic resistance in tobacco. Virology 80, 417-420

70 Boller T, Gehri A. Mauch F, Vögeli U (1983) Chitinase in bean leaves: induction by ethylene, purification, properties, and possible function. Planta 157, 22-31

71 Mauch F, Staehelin LA (1989) Functional implications of the subcellular localization of ethylene-induced chitinase and $\beta-1,3-$ glucanase in bean leaves. Plant Cell 1, 447457

72 Keefe D, Hinz U, Meins F (1990) The effect of ethylene on the cell-type-specific and intracellular localization of the $\beta-1,3-$ glucanase and chitinase in tobacco leaves. Planta 182, 43-51
73 Lotan T, Fluhr R (1990) Xylanase, a novel elicitor of pathogenesis-related proteins in tobacco, uses a non-ethylene pathway for induction. Plam Physiol 93, 81 1-817

74 Samac DA, Hironaka CM, Yallaly PE, Shah DM (1990) Isolation and characterization of the genes encoding basic and acidic chitinase in Arabidopsis thaliana. Plant Physiol 93, 907-914

75 Brederode FT, Linthors $\sharp$ HJM, Bol JF (1991) Differential induction of acquired resistance and PR gene expression in tobacco by virus, infection, ethephon treatment. UV light and wounding. Plant Mol Biol 17, 1117-1125

76 Eyal Y, Sagee O, Fluhr R (1992) Dark-induced accumulation of a basic pathogenesis-related (PR-1) transcript and a light requirement for its induction by ethylene. Plant Mol Biol 19, 589-599

77 Mauch F, Meehl JB, Staehelin LA (1992) Ethyleneinduced chitinase and $\beta-1,3-$ glucanase accumulate specifically in the lower epidermis and along vascular strands of bean leaves. Planta 186, 367-375

78 Castresana C, De Carvalho F, Gheysen G, Habets M, Inzé D, Van Montagu M (1990) Tissue-specific and pathogen-induced regulation of a Nicotiana plumbaginifolia B-1,3-glucanase gene. Plant Cell 2, 1131-1143

79 Côté F, Cutt JR, Asselin A, Klessig DF (1991) Pathogenesis-related acidic $\beta$-1,3-glucanase genes of tobacco are regulated by both stress and developmental signals. Mol Plant Microbe Inter. 4, 173-181

80 Fraser RSS (1981) Evidence for the occurrence of the 'Pathogenesis-Related' proteins in leaves of healthy tobacco plants during flowering. Physiol Plant Pathol 19. 69-76

81 Lotan T, Ori N, Fluhr R (1989) Pathogenesis-rolated proteins are developmentally regulated in tobacco flowers. Plant Cell 1, 881-887

82 Neale AD, Wahleithner JA, Lund M, Bonnett HT, Kelly A. Meeks-Wagner RD, Peacock WJ, Dennis ES (1990) Chitinase. $\beta$-1,3-glucanase, osmotin, and extensin are expressed in tobacco explants during flower formation. Plaint Cell 2, 673-684

83 Leung DWM (1992) Involvement of plant chitinase in sexual reproduction of higher plants. Phytochemistey 31, 1899-1900

84 Richard L, Arro M, Hoebeke J, Meeks-Wagner RD, Tran Thanh Van K (1992) Immunological evidence of thaumatin-like proteins during tobacco floral differentiation. Plant Pliysiol 98, 337-342

85 Malamy J, Carr JP, Klessig DF, Raskin I (1990) Salicylic acid: a likely endogenous signal in the resistance response of tobacco to viral infection. Science 250, I002-1004

86 Métraux JP, Signer H, Ryals J, Ward E, Wyss-Benz M. Gaudin J, Raschdorf K, Schmid E, Blum W, Inverardi B (1990) Increase in salicylic acid at the onset of systemic acquired resistance in cucumber. Science 250, 1004-1006

87 Enyedi AJ, Yalpani N, Silverman P, Raskin I (1992) Localization, conjugation, and function of salicylic acid in tobacco during the hypersensitive reaction to tobacco mosaic virus. Proc Natl Acad Sci USA 89, 2480-2484

88 Rodrigo I, Vera P, Van Loon LC, Conejero V (1991) Degradation of tobacco pathogenesis-related proteins. Evidence for conserved mechanisms of degradation of pathogenesis-related proteins in plants. Plant Physiol 95. 616-622

89 Antoniw JF, Ritter CE, Pierpoint WS, Van Loon LC (1980) Comparison of three pathogenesis-related proteins from plants of two cultivars of tobacco infected with TMV. J Gen Virol 47.79-87 
90 Kautfmann S (1988) Les protéines PR (pathogenesisrelated) du tabac: des protéines impliquées dans les réactions de défense aux agents phytopathogènes. Isolement, propriétés sérologiques et activités biologiques. Thèse de I'Université de Strasbourg

91 Kauffmann S, Legrand $M$, Geoffroy P, Fritig B (1987) Biological function of pathogenesis-related proteins: four PR proteins of tobacco have 1,3- $\beta$-glucanase activity. $E M B O J 6,3209-3212$

92 Legrand M. Kauffmann S, Geoffroy P, Fritig B (1987) Biological function of pathogenesis-related proteins: four tobacco pathogenesis-related proteins are chitinases. Proc Natl Acad Sci USA 84, 6750)-6754

93 Kombrink E, Schroder M. Hahlbrock K (1988) Several 'pathogenesis-related' proteins in potato are 1,3- $\beta$-glucanases and chitinases. Proc Notl Acad Sci USA 85, 782786

94 Nasser W, De Tapia M, Kauffmann S, Montasser-Kouhsari S, Burkard G (1988) Identification and characterization of maize pathogenesis-related proteins. Four maize PR proteins are chitinases. Plam Mol Biol 11. 529-538

95 Awade A, De Tapia M, Didier jean L, Burkard G (1989) Biological function of bean pathogenesis-related (PR 3 and PR 4) proteins. Plami Sci 63, 121-130

96 Fischer W, Christ U, Baumgai tner M. Erismann KH, Mösinger E (1989) Pathogenesis-related proteins of tomato: II. Biochemical and immunological characterization. Plyysiol Mol Plait Pathol 35.67-83

97 Joosten MHA, De Wit PJGM ( $19 \% 9)^{\prime}$ 'dentitication of several pathogencsis-relatiod proteins in romato leaves inoculated with Cladosporium fiulutum (syn Fulvia fielva) as 1,3- $\beta$-glucantases and chitinases. Plant Physiol 89. 945-951

98 Vogelsang R, Barz W (1990) Elicitation of $\beta$-1,3-glucamase and chitinase activitics in cell suspension cultures of A.rcorhyta rabici resistumt and susceptible cultivars of chickpea (Cic'er arictimum). ¿ Narmifenisch 45c, 233-239

99 Fritig B. Roustcr J, Kauffmann S. Stintzi A, Geoff'roy P, Kopp M. Legrand M (1989) Virus-indisced glycianhydrolases and effects of oligosaccharide signals on plant-virus intcractions. In: Signal Molecules in Plants and PlantMirrobe Intercactions (Lugtenberg BJJ, ed), Nato ASI Series H: Cell Biology, Vol 36. Springer Verlag, Berlin, 161-168

100 Antoniw JF, Pierpoint WS (1978) The puritication and properties of one of the ' $b$ ' proteins from virus-infected tobacco plants. J Gin Virol 39, 343-350

101 Antoniw JF, White RF, Barbara DJ, Jones P, Longley A (1985) The detection of PR (b) protein and TMV by ELISA in systemic and localised virus infections of tobacco. Plaint Mol Biol 4, 55-60

102 Nassuth A, Sínger I-IL (1986) Immunological relationship between 'pathogenesis-related' leaf proteins from tomato, tobacco and cowpea. Virus Res 4, 229-242

103 White RF, Rybicki EP, Von Wechmar MB, Dekker JL, Antoniw JF (1987) Detection of PR I-type proteins in Amaranthaceae, Chenopodiacecac. Graminare and Solanac'ese by immunoelectroblotting. J Gen Virol 68, 2043-2048

104 Hooft van Huijsduijnen RAM, Cornelissen BJC, Van Loon LC, Van Boom JH, Tromp M, Bol J F (1985) Virusinduced synthesis of messenger RNAs for precursors of pathogenesis-related proteins in tobacco. EMBO .I 4. $2167-21 \% 1$

105 Cornelissen BJC, Hooft van Huijsduijnen RAM, Van Loon LC. Bol JF (1986) Molecular characterization of messenger RNAs for 'pathogenesis-related' proteins la, $\mathrm{lb}$ and $\mathrm{Ic}$, induced by TMV infection of tobacco. EMBO J 5, 37- 40

106 Matsuoka M. Yamamoto N, Kano-Murakami Y. Tanaka Y, Ozeki Y, Hirano $H$. Kagawa H, Oshima M, Ohashi $Y$ (1987) Classification and structural comparison of fulllength cDNAs for pathogenesis-related proteins. Plant Physiol 85, 942-946

107 Pfitzner UM, Goodman HM (1987) Isolation and characterization of cDNA clones encoding pathogenesis-related proteins from tobacco mosaic virus infected tobacco plants. Nucleic Acids Res 15, 4449-4465

108 Cutt JR, Dixon DC, Carr JP, Klessig DF (1988) Isolation and nucleotide sequence of cDNA clones for the pathogenesis-related proteins PRIa, PRIb and PRI c of Nicotiana rabacum cv. Xanthi nc induced by TMV infection. Nucleic Acids Res 16, 9861

109 Cornelissen BJC, Horowitz J, Van Kan JAL, Goldberg RB. Bol JF ( 1987) Structure of tobacco genes encoding pathogenesis-related proteins from the PR-1 group. Nucleic Acids Res 15, 6799-.6811

110 Payne G, Middlesteadt W. Desai N, Williams S, Dincher S, Carnes M, Ryals J (1989) Isolation and sequence of a genomic clone encoding the basic form of pathogenesisrelated protein 1 from Nicotiana tabacum. Plant Mol Biol 12, 595-596

111 Van Loon LC (1990) Letter to the editor. The nomenclature of pathogenesis-related proteins. Physiol Mol Plant Patkol 37, 229-230

112 Lucas J, Camacho Henriquez A, Lottspeich F, Henschen A, Sanger HL (1985) Amino acid sequence of the "pathogenesis-rclated' leaf protein pl4 from viroid-infected tomato reveals a new type of structurally unfamiliar proteins. EMBO I 4, 2745-2749

113 Linthorst HJM, Meuwissen RLJ, Kauffmann S, Bol JF (1989) Constitutive expression of pathogenesis-related proteins PR-I, GRP, and PR-S in tobacco has no eff ect on virus infection. Plant Cell 1, 285-29l

114 Cutt JR, Harpster MH, Dixon DC, Carr JP, Dunsmuir P, Klessig DF (1989) Disease response to tobacco mosaic virus in transgenic tobacco plants that constitutively express the pathogenesis-related PR Ib gene. Virologsy 173, 89-97

115 Niderman T, Bruyère T, Giigler K, Mösinger E (1993) Antifungal activity of native and recombinant tomato $\mathrm{PI} 4$ proteins. In: Mechanisms of Plant Defense Responses (Fritig B, Legrand M, eds), Kluwer Academic Publishers, Dordrecht, 450

116 Boller T (1988) Ethylene and the rugulation of antifungal hydrolases in plants. In: Oxford Surveys of Plant Mole. cular and Cell Biology (Miflin BJ, ed), vol 5, Oxford University Press, Oxford, 145-174

117 Meins F, Neuhaus JM, Sperisen C, Ryals J (1992) The primary structure of plant pathogenesis-related glucanohydrolases and their genes. In: Genes Involved in Plant Defense (Meins F, Boller T, eds), Springer-Verlag, Vienna/New York, 245-282

118 Payne G. Ward E, Gafiney T, Ahl P. Moyer M, Harper A. Meins F, Ryals J (1990) Evidence for a third structural class of $\beta$-1,3-glucanase in tobacco. Plant Mol Biol 15, 797-808

119 Linthorst HJM, Melchers LS, Mayer A, Van Roekel JSC, Cornelissen BJC, Bol JF (1990) Analysis of gene families encoding acidic and basic $\beta-1,3$ glucanases of tobacco. Proc Narl Acrad Sci USA 87, 8756-8760

120 Ward ER, Payne GB, Moyer MB, Williams SC, Dincher SS, Sharkey KC, Beck JJ, Taylor HP, Ahl-Goy P, Meins F, 
Ryals JA (1991) Differential regulation of $\beta$-1,3-glucanase messenger RNAs in response to pathogen infection. Plant Physiol 96, 390-397

121 Van den Bulcke M, Bauw G, Castresana C, Van Montagu M, Vandekerckhove J (1989) Characterization of vacuolar and extracellular $\beta(1,3)$-glucanases of tobacco: evidence for a strictly compartmentalized plant defense system. Prcc Natl Acad Sci USA 86, 2673-2677

122 Ham KS, Kauffmann S, Albersheim P, Darvill AG (1991) Host-pathogen interactions XXXIX. A soybean pathogenesis-related protein with $\beta$-1,3-glucanase activity releases phytoalexin elicitor-active heat-stable fragments fiom fungal walls. Mol Plant Microbe Inter 4, 545-552

123 Collinge DB, Kragh KM, Mikkelsen JD, Nielsen KK, Rasmussen U, Vad K (1993) Plant chitinases. Plant J 3, $31-40$

124 Roberts WK, Selitrennikoff CP (1988) Plant and bacterial chitinases differ in antifungal activity. $J$ Gen Microbiol 134, 169-176

125 Trudel J, Audy P, Asselin A (1989) Electrophoretic forms of chitinase activity in Xanthi-nc tobacco, healthy and infected with tobacco mosaic virus. Mol Plant Microbe Inter 2, 315-324

126 Bemier I, Van Leemputten E, Horisberger M, Bush DA, Jollès P (1971) The tumip lysozyme. FEBS Lett 14, 100104

127 Majeau N, Trudel J. Asselin A (1990) Diversity of cucumber chitinase isoforms and charaterization of one seed basic chitinase with Iysozyme activity. Plant Sci 68, 9-16

128 Audy P, Trudel J, Asselin A (1988) Purification and characterization of a lysozyme from wheat genn. Plant Sci $58,43-50$

129 Grenier J, Asselin A (1990) Some pathogenesis-related proteins are chitosanases with lytic activity against fungal spores. Mol Plant Microbe Inter 3, 401-407

130 Hooft van Huijsduijnen RAM, Kauffmann S, Brederode FT, Comelissen BJC, Legrand M, Fritig B, Bol JF (1987) Homology between chitinases that are induced by TMV infection of tobacco. Plant Mol Biol 9, 411-420

131 Métraux JP, Burkhart W, Moyer M, Dincher S, Middlesteadt W, Williams S, Payne G, Carnes M, Ryals J (1989) Isolation of a complementary DNA encoding a chitinase with structural homology to a bifunctional lysozyme/ chitinase. Proc Natl Acad Sci USA 86, 896-900

132 Lawton K, Ward E, Payne G, Moyer M, Ryals J (1992) Acidic and basic class IIl chitinase mRNA accumulation in response to TMV infection of tobacco. Plant Mol Biol 19, 735-743

133 Stintzi A, Geoffroy P. Bersuder D, Fritig B, Legrand M (1993) cDNA cloning and expression studies of tobacco class III chitinase-lysozymes. In: Mechanisms of Plant Defense Responses (Fritig B, Legrand M, eds) Kluwer Academic Publishers, Dordrecht, 312-315

134 Broekaert WF, Van Parijs J, Allen AK, Peumans WJ (1988) Comparison of some molecular, enzymatic and antifungal properties of chitinases from thom-apple, tubacco and wheat. Physiol Mol Plant Pathol 33, 319-331

135 Rousseau-Limouzin M, Fritig B (1991) Induction of chitinases, $1,3-\beta$-glucanases and other pathogenesis-related proteins in sugar beet leaves upon infection with Cercospora beticola. Plant Physiol Biochem 29, 105-1 17

136 Neuhaus JM, Sticher L, Meins F, Boller T (1991) A short C-terminal sequence is necessary and sufficient for the targeting of chitinases to the plant vacuole. Proc Natl Acad Sci USA 88, 10362-10366
137 Broglie KE, Gaynor JJ, Broglie RM (1986) Ethyleneregulated gene expression: molecular cloning of the genes encoding an endochitinase from Phaseolus vulgaris. Proc Natl Acad Sci USA 83, 6820-6824

138 Gaynor JJ (1988) Primary structure of an endochitinase mRNA from Solanum tuberosum. Nucleic Acids Res 16, 5210

139 Parsons TJ, Bradshaw HD, Gordon MP (1989) Systemic accumulation of specific mRNAs in response to wounding in poplar trees. Proc Natl Acad Sci USA 86, 78957899

140 Shinshi H, Neuhaus JM, Ryals J, Meins F (1990) Structure of a tobacco endochitinase gene: evidence that different chitinase genes can arise by iransposition of sequences encoding a cysteine-rich domain. Plant Mol Biol 14, 357-368

141 Swegle M, Huang JK, Lee G, Muthukrishnan S (1989) Identification of an endochitinase cDNA clone from barley aleurone cells. Plant Mol Biol 12, 403-412

142 Huang JK, Wen L, Swegle M, Tran HC, Thin TH, Naylor HM, Muthukrishnan S, Reeck GR (1991) Nucleotide sequence of a rice genomic clone that encodes a class I endochitinase. Plant MolBiol 16, 479-480

143 Vad K, Mikkelsen JD, Collinge DB (1991) Induction, purification and characterization of chitinase isolated from pea leaves inoculated with Ascochyta pisi. Planta 184, 24-29

144 Margis-Pinheiro M, Metz Boutigue MH, Awade A, De Tapia M, Le Ret M, Burkard G (1991) Isolation of a complementary DNA encoding the bean PR4 chitinase: an acidic enzyme with an amino-terninus cysteine-rich domain. Plant Mol Biol 17, 243-253

145 Abeles FB, Bosshart RP, Forrence LE, Habig WH (1971) Preparation and purification of glucanase and chitinase from bean leaves. Plam Physiol 47, 129-134

146 Pegg GF, Young DH (1982) Purification and characterization of chitinase enzymes from healthy and Verticiliumalbo-arrum-infected tomato plants, and from $V$ alboatrum. Physiol Plant Pathol 21, 389-409

147 Boller $T$ (1993) Antimicrobial functions of the plant hydrolases, chitinase and $\beta-1,3$-glucanase. In: Mec/hanisms of Plant Defense Responses (Fritig B, Legrand M, eds) Kluwer Academic Publishers, Dordrecht, 391400

148 Schlumbaum A, Mauch F, Vögeli U, Boller T (1986) Plant chitinases are potent inhibitors of fungal growth. Nature 324, 365-367

149 Verburg JG, Huynh QK (1991) Purification and characterization of an antifungal chitinase from Alabidopsis thaliana. Plant Physiol 95, 450-455

150 Broglie K. Chet I, Holliday M, Cressman R, Biddle P, Knowlton S, Mauvais CJ, Broglie R (1991) Transgenic plants with enhanced resistance to the fungal pathogen Rhizoc'tonia solani. Scienc'e 254, 1194-1197

151 Mauch F, Mauch-Mani B, Boller T (1988) Antifungal hydrolases in pea tissue. II. Inhibition of fungal growth by combinations of chitinase and $\beta-1,3$-glucanase. Plant Physiol 88, 936-942

152 Ludwig A, Boller T (1990) A method for the study of fungal growth inhibition by plant proteins. FEMS Microbiol Lett 69, 61-66

153 Sela-Burlage MB, Ponstein AS, Bres-Vloemans SA, Melchers LS, Van den Elzen PJM, Cornelissen BJC (1993) Only specific tobacco (Nicotiana tahacum) chitinases and $\beta$-1,3-glucanases exhibit antifungal activity. Plant Physiol 101, 857-863 
154 Melchers LS. Ponstein AS, Sela-Burlage MB, Vloemans SA. Comelissen BJC (1993) In vitro anti-microbial activities of defense proteins and biotechnology. In: Mechanisms of Plant Defense Responses (Fritig B, Legrand M, eds), Kluwer Academic Publishers, 401410

155 Boijsen K, Nielsen KK, Gottschalk T, Mikkelsen JD (1993) Genetic transformation of Nicotiana benthamiana with chitinase and $\beta-1,3$-glucanase genes from Beta vulgaris. (sugar beet). In: Mechanisms of Plant Defense Responses (Fritig B, Legrand M, eds), Kluwer Academic Publishers, Dordrecht, 449

156 Benhamou N, Grenier J, Asselin A, Legrand M (1989) Immunogold localization of $\beta$-1,3-glucanases in two plants infected by vascular wilt fungi. Plant Cell 1, 1209-1221

157 Benhamou N, Joosten MHA, De Wit PJGM (1990) Subcellular localization of chitinase and of its potential substrate in tomato root tissues infected by Fusarium oxysporum f sp radicis-lycopersici. Plant Physiol 92. $1108-1120$

158 Benhamou $N$ (1993) Spatio-temporal regulation of defence genes: immunocytochemistry. In: Mechanisms of Plant Defense Responses (Fritig B, Legrand M, eds), Kluwer Academic Publishers, Dordrecht, 221-235

159 Lamb CJ, Ryals JA, Ward ER, Dixon RA (1992) Emerging straiegies for enhancing crop resistance to microbial pathogens. Bio/tec/mology 10, 1436-1445

160 Cornelissen BJC, Melchers LS (1993) Strategies for control of fungal diseases with transgenic plants. Plant Physiol 101, 709-712

161 Broglie R, Broglie K (1593) Chitinases and plant protection. In: Mechanisms of Plam Def'ense' Responses (Fritig B, Legrand M, eds), Kluwer Academic Publishers, Dordrecht, $411-421$

162 Benhamou N, Broglie K. Chet 1, Broglie R (1993) Antifungal effect of bean endochitinase on Rhizoctemia solcmi: ultrastructure changes and cytochemicil aspects of chstin breakdown. C(III) J Microbiol, in press

163 Jach G, Logemann S, Wolf G, Oppenheim H. Chet I, Schell J, Logemann J (1992) Expression of a bacterial chitinase leads to improved resistance of transgenic tobacco plants against fungal infection. Biopractice 1, 1-9

164 Vierheilig H, Alt M, Neuhaus JM, Boller T, Wiemken A (1993) Colonization of transgenic Nicotiana syliestris plants, expressing differents forms of Nicotiana tabacum chitinase, by the root pathogen Rlizoctomia solani and by the mycorrhizial symbiont Glomus mos.sae. Mol Plant Microbe Inter 6, 261-264

165 Düring K, Fladung M, Lörz H (1993) Antibacterial resistance of transgenic potato plants producing $\mathrm{T} 4$ lysozyme. In: Mechanisms of Plant Defense Responses (Fritig B, Legrand M, eds) Kluwer Academic Publishers, Dordrecht, 437-440

167 Ryan CA, Farmer EE (1991) Oligosaccharide signals in plants: a current assessment. Anmı R('y Plant Physiol Plani Mol Biol 42, 651-674

168 Hahn MG, Cheong JJ, Alba R. Enkerli J. Côté F (1993) Oligosaccharide elicitors: structures and recognition. In: Mechanisms of Plant Defense Responses (Fritig B, Legrand $M$, eds), Kluwer Academic Publishers, Dordrecht, 99-116

169 Barber MS, Bertram RE, Ride JP (1989) Chitin oligosaccharides elicit lignification in wounded wheat leaves. Physiol Mol Plant Pathol 34, 3-12
170 Kendra DF, Christian D, Hadwiger LA (1989) Chitosan oligomers from Fusarium solani pea interactions, chitinase/ $\beta$-glucanase digestion of sporelings and from fungal wall chitin actively inhibit fungal growth and enhance disease resistance. Physiol Mol Plant Pathol 35, 215-230

171 Roby D, Gadelle A, Toppan A (1987) Chitin oligosaccharides as elicitors of chitinase activity in melon plants. Biochem Biophys Res Commun 143, 885-892

172 Parker JE, Hahlbrock K, Scheel D (1988) Different cellwall components from Phytophthora megasperma f sp glycinea elicit phytoalexin production in soybean and parsley. Planta 176, 75-82

173 Ricci P, Bonnet P, Huet JC, Sallantin M, Beauvais-Cante F, Bruneteau M, Billard V, Michel G, Pernollet JC (1989) Structure and activity of proteins from pathogenic fungi Phytophthora eliciting necrosis and acquired resistance in tobacco. Eur J Biochem 183, 555-563

174 Parker JE. Schulte W, Hahlbrock K, Scheel D (1991) An extracellular glycoprotein from Phytophthora megasperma f sp glycinea elicits phytoalexin synthesis in cultured parsley cells and protoplasts. Mol Plant Microbe Inter 4, 19-27

175 Ricci P, Panabières F, Bonnet $P$, Maia N, Ponchet M, Devergne JC, Marais A, Cardin L, Milat ML, Blein JP (1993) Proteinaceous elicitors of plant defense responses. In: Mechanisms of Plant Defense Responses (Fritig B, Legrand M, eds), Kluwer Academic Publishers, Dordrecht, $121-135$

176 Sharp JK, Valent B, Albersheim P (1984) Purification and partial characterization of a $\beta$-glucan fragment that elicits phytoalexin accumulation in soybean. J Biol Chem 259 , $11312-11320$

177 Sharp JK, McNeil M, Albersheim P (1984) The primary structures of one elicitor-active and seven elicitor-inactive hexa( $\beta-D$-glucopyranosyl)-D-glucitols isolated from the mycelial walls of Phytophthora megaspervina f $\mathrm{sp} g / \mathrm{y}$ cinea. J Biol Chem 259, 11321-11336

178 Keen NT, Yoshikawa M (1983) $\beta-1,3-E n d o g l u c a n a s e$ from soybean releases elicitor-active carbohydrates from fungus cell walls. Plant Physiol 71, 460 -465

179 Takeuchi Y, Yoshikawa M, Takeba G, Tanaka K, Shibata D, Horino O (1990) Molecular cloning and ethylene induction of mRNA encoding a phytoalexin elicitor-releasing factor, $\beta-1,3-e n d o g l u c a n a s e$, in soybean. Plant Physiol 93, 673-682

180 Yoshikawa M, Takeuchi Y, Horino O (19y0) A mechanism for ethylene-induced disease resistance in soybean: enhanced synthesis of an elicitor-releasing factor, $\beta-1,3-$ glucanase. Physiol Mol Plant Pathol 37, 367-376

181 Kauffmann S, Legrand M, Fritig B (1990) Isolation and characterization of six pathogenesis-related (PR) proteins of Samsun NN tobacco. Plant Mol Biol 14, 381-390

182 Friedrich L, Moyer M, Ward E, Ryals J (1991) Pathogenesis-related protein 4 is structurally homologous to the carboxy-terminal domains of hevein, Win-1 and Win-2. Mol Gen Genet 230, 113-119

183 Linthorst HJM, Danhash N, Biederode FT, Van Kan JAL, De Wit PJGM, Bol JF (1991) Tobacco and tomato PR proteins homologous to win and Pro-hevein lack the 'hevein' domain. Mol Plant Microbe Inter 4, 586592

184 Joosten MHA, Bergmans CJB, Meulenhoff EJS, Cornelissen BJC, De Wit PJGM (1990) Purification and serological characterization of three basic 15-kilodalton pathogenesis-related (PR) proteins from tomato. Plant Physiol 94, 585-591 
185 Pierpoint WS, Tatham AS, Pappin DJC (1987) Identification of the virus-induced protein of tobacco leaves that resembles the sweet-protein thaumatin. Physiol Mol Plant Pathol 31, 291-298

186 Stintzi A, Heitz T, Kauffmann S, Legrand M, Fritig B (1991) Identification of a basic pathogenesis-related, thaumatin-like protein of virus-induced tobacco as osmotin. Physiol Mol Plant Pathol 38, 137-146

187 Singh NK, Bracker CA, Hasegawa PM, Handa AK, Buckel S, Hernodson MA, Pfankoch E, Regnier FE, Bressan RA (1987) Characterization of osmotin. A thaumatin-like protein associated with osmotic adaptation in plant cells. Plant Physiol 85, 529-536

188 Parent JG, Asselin A (1984) Detection of pathogenesisrelated proteins (PR or $b$ ) and of other proteins in the intercellular fluid of hypersensitive plants infected with tobacco mosaic virus. Can J Bot 62, 564-569

189 Dore 1, Legrand M, Comelissen BJC, Bol JF (1991) Subcellular localization of acidic and basic PR proteins in tobacco mosaic virus-infected tobacco. Arch Virol 120. 97-107

190 Comelissen BJC, Hooft van Huisdui jnen RAM, Bol JF (1986) A tobacco mosaic virus-induced tobacco protein is homologous to the sweet-tasting protein thaumatin. Nature 321, 531-532

191 Payne G, Middlestadt W, Williams S, Desai N, Parks TD, Dincher S, Cames M, Ryals J (1988). Isolation and nucleotide sequence of a novel cDNA clone encoding the major forn of pathogenesis-related protein R. Plant Mol Biol 11, 223-224

192 Singh NK, Nelson DE, Kuhn D, Hasegawa PM, Bressan RA (1989) Molecular cloning of osmotin and regulation of its expression by $\mathrm{ABA}$ and adaptation to low water potential. Plant Physiol 90, 1096-1101

193 Richardson M, Valdes-Rodriguez S, Blanco-Labra A (1987) A possible function for thaumatin and a TMV. induced protein suggested by homology to a maize inhibitor. Nature 327, 432-434

194 King GJ, Tumer VA, Hussey CE, Syrkin Wurtele E, Lee SM (1988) Isolation and characterization of a tomato cDNA clone which codes for a salt-induced protein. Plant Mol Biol 10, 401-412

195 Bryngelsson T, Green B (1989) Characterization of a pathogenesis-related, thaumatin-like protein isolated from barley challenged with an incompatible race of mildew. Physiol Mol Plant Pathol 35, 45-52

196 Pierpoint WS, Jackson PJ, Evans RM (1990) The L. ...ence of a thaumatin-like protein, a chitinase and a z.ucanase among the pathogenesis-related proteins of potato (Solanum tuberosum). Phy siol Mol Plant Pathol 36, 325-338

197 Hejgaard J, Jacobsen S, Svendsen 1 (1991) Two antifungal thaumatin-like proteins from barley grain. FEBS Lett 291, 127-131

198 Sehgal OP, Rieger R, Mohamed F (1991) Induction of bean PR-4d-type protein in divergent plant species after infection with tobacco ringspot virus and its relationship with tobacco PR-5. Phytopathology 81, 215-219

199 Vigers AJ, Roberts WK, Selitrennikoff CP (1991) A new family of plant antifungal proteins. Mol Plant Microbe Inter 4, 315-323

200 Woloshuk CP, Meulenhoff JS, Sela-Buurlage M, Van den Elzen PJM, Cornelissen BJC (1991). Pathogen-induced proteins with inhibitory activity toward Phytophthora infestans. Plant Cell 3, 619-628

201 Graham JS, Burkhart W, Xiong J, Gillikin JW (1992) Complete amino acid sequence oí soybean leaf P21.
Similarity to the thaumatin-like polypeptides. Plant Physiol 98, 163-165

202 Van Kan JAL, Van De Rhee MD, Zuidema D, Cornelissen BJC, Bol JF (1989) Structure of tobacco genes encoding thaumatin-like proteins. Plant Mol Biol 12, 153-155

203 Nelson DE, Raghothama KG, Singh NK, Hasegawa PM, Bressan RA (1992) Analysis of structure and transcriptional activation of an osmotin gene. Plant Mol Biol 19, 577-588

204 Albrecht H, Van de Rhee MD, Bol JF (1992) Analysis of cis-regulatory elements involved in induction of a tobacco PR-5 gene by virus infection. Plant Mol Biol 18, 155-158

205 Rodrigo I, Vera P, Frank R, Cone jero V (1991) Identification of the viroid-induced tomato pathogenesis-related (PR) protein P23 as the thaumatin-like tomato protein NP24 associated with osmotic stress. Plant Mol Biol 16, 931-934

206 Takeda S, Sato F, Ida K, Yamada Y (1991) Nucleotide sequence of a cDNA for osmotin-like protein from cultured tobacco cells. Plant Physiol 97, 844-846

207 Casas AM, Nelson DE, Raghothama KG, Paino D'Urzo M, Singh NK, Bressan RA, Hasegawa PM (1992) Expression of osmotin-like genes in the halophyte Atriplex numularia L. Plant Physiol 99, 329-337

208 Kumar V, Spencer ME (1992) Nucleotide sequence of an osmotin cDNA from the Nicotiana tabacum cv White Burley generated by the polymerase chain reaction. Plant MolBiol 18, 621-622

209 Vigers AJ, Wiedemann S, Roberts WK, Legrand M, Selitrennikoff CP, Fritig B (1992) Thaumatin-like pathogenesis-related proteins are antifungal. Plant Sci 83, 155-161

210 Roberts WK. Selitrennikoff CP (1990) Zeumatin, an antifungal protein from maize with membrane-permeabilizing activity. J Gen Microbiol 136, 1771-1778

211 Bohlmann H, Apel K (1991) Thionins. Antm Rev Plant Physiol Plant Mol Biol 42, 227-240

212 Jung JL, Fritig B. Hahne G (1993) Sunljower (Helianthus annutus L) pathogenesis-related proteins. Induction by aspirin (Acetylsalicylic acid) and characterization. Plant Physiol 101, 873-880

213 Heitz T, Geoffroy P, Fritig B, Legrand M (1991) Two apoplastic $\alpha$-amylases are induced in tobacco by virus infection. Plant Physiol 97, 651-656

214 Geoffroy P, Legrand M, Fritig B (1990) Isolation and characterization of a proteinaceous inhibitor of microbial proteinases induced during the hypersensitive reaction of tobacco to tobacco mosaic virus. Mol Plant Microbe Inter 3, 327-333

215 Heitz T, Geoffroy P, Stintzi A, Fritig B, Legrand M (1993) cDNA cloning and gene expression analysis of the microbial proteinase inhibitor of tobacco. $J$ Biol Chem, in press

216 Ryan CA (1990) Protease inhibiturs in plants: genes for improving defenses against insects and pathogens. Antm Rev Phytopathol 28, 425-449

217 Lagrimini LM, Rothstein S (1987) Tissue-specificity of tobacco peroxidase isozymes and their induction by wounding and tobacco mosaic infection. Plant Physiol 84, 438- 442

218 Lagrimini LM, Burkhart W, Moyer M, Rothstein S (1987) Molecular cloning of complementary DNA encoding the lignin-forming peroxidase from tobacco: molecular analysis and tissue-specific expression. Proc Natl Acad Sci USA 84, 7542-7546 
219 Massala R. Legrand M, Fritig B (1980) Effect of $\alpha$-aminooxyacetate, a compelitive inhibitor of phenylalanine ammonia-lyase, on the hypersensitive resistance of tobacco to tobacco mosaic virus. Physiol Plant Fathol 16. 213-226

220 Massala R, Legrand M, Fritig B (1987) Comparative effects of two competitive inhibitors of phenylalanine ammonia-lyase on the hypersensitive resistance of tobacco to tobacco mosaic virus. Plant Physiol Biochem 25, 217-225

221 Jaeck E, Dumas B, Geoffroy P, Favet N, Inzé D, Van Montagu M. Fritig B. Legrand M (1992) Regulation of enzymes involved in lignin biosynthesis: induction of $O$ methyltransferase mRNAs during the hypersensitive reaction of tobacco to tobacco mosaic virus. Mol Plant Microbe Inter 5, 294-300

222 Edelbaum O, Ilan N, Grafi G, Sher N, Stram Y, Novick D, Tal N, Sela I. Rubinstein M (1990) Two antiviral proteins from tubacico: purificativis and cliasaclerization by monoclonal antibodies to human -interferon. Proc Nat Acad Sci USA 87, 588-592

223 Edelbaum O. Sher N, Rubinstein M, Novick D, Tal N, Moyer M. Ward E, Ryals J, Sela I (1991) Two antiviral proteins, gp35 and gp22, correspond to $\boldsymbol{\beta}$-1.3-glucanasi and an isoform of PR-5. Plant Mol Biol 17, 171-173

224 Huynh QK, Borgmeyer JR. Zobel JF (1992) Isolation and characterization of a $22 \mathrm{kDa}$ protein with antifungal properties from maize seeds. Biochem Biophys Res Commun $182,1-5$

225 Payne G, Ahl P, Moyer M, Harper A, Beck J, Meins F, Ryals J (1990) Isolation of complementary DNA clones encoding pathogenesis-related proteins $P$ and $Q$, two acidic chitinases from tobacco. Proc Natl Acad Sci USA 87, 98-102

226 Linthorst HJM, Van Loon LC, Van Rossum CMA, Mayer A, Bol JF, Van Roekel JSC, Meulenhoff EJS, Cornelissen BJC (1990) Analysis of acidic and basic chitinases from tobacco and petunia and their constitutive expression in transgenic tobacco. Mol Plant Microbe Inter 3, 252-258

227 Kauffmann S, Bailleul F, Genetet I, Kopp M, Fritig B (1993) Two ploteitis suncicul by Phytophthora megasperma elicit necrosis and defence-related responses in tobacco. In: Mechanisms of Plant Defense Responses (Fritig B, Legrand M. eds) Kluwer Academic Publishers, Dordrecht, 140-143 